\title{
Nov pogled na spomenike v pokrajini Črnega pasu: načrtovanje, spomin in identiteta Afroameričanov v Alabami
}

Čeprav so mnogi stari kraji v ZDA dobro ohranjeni, veliko območij zgodovinske in kulturne vrednosti zaradi opuščanja izginja. V nekaterih primerih imajo restavratorji zaradi stanja teh krajev težko delo, $\mathrm{v}$ drugih primerih pa uprave in kulturne ustanove za izboljšanje lokalnega gospodarstva uvajajo strateške prostorske načrte, $s$ katerimi želijo pritegniti turiste in urediti zgodovinske tematske parke. Novejše raziskave odnosa med zgodovino in kolektivnim spominom pa so ta območja postavile pod drobnogled. Čeprav spomin za nekatera zgodovinska območja hitro izgineva, dobiva več pozornosti kot $\mathrm{v}$ preteklosti, $s$ čimer se krepita lokalna identiteta in občutek pripadnosti skupnosti. $V$ članku je obravnavano več načrtov in načrtovalskih strategij, ki so bili razviti za oblikovanje spomeniške pokrajine v Alabami, dokumentirani in preučeni pa so tudi nekateri ključni odnosi med načrtovanjem mest in obeleževanjem zgodovine Afroameričanov.

Ključne besede: Alabama, Afroameričani, spomenik, ameriška pokrajina, Črni pas 


\section{Uvod}

Alabama je v drugi polovici 19. stoletja postala pomembna proizvajalka bombaža. Mesta $\mathrm{v}$ državi so tradicionalno delovala kot središča trgovine $s$ sužnji, ki se je zgoščala okrog pristanišč in tržnic (Reps, 1992). Povezave med posameznimi trgi bombaža v regiji je krepilo železniško omrežje. V obdobju čezatlantske trgovine s sužnji med letoma 1625 in 1864 naj bi bilo v ZDA prepeljano okrog pol milijona Afričanov (Curtain, 1969; Anstey, 1970; Hamilton, 1977). Večino okrožii, še posebej tistih v bližini reke Alabame, ki se izliva v zaliv reke Mobile in nato v Mehiški zaliv, povezuje zapletena mreža vodotokov. Leta 1864 je bilo suženjstvo uradno ukinjeno na podlagi trinajstega amandmaja ameriške ustave, vendar je bil ta zakon samo del zakonodajnih prizadevanj za popolno osvoboditev afroameriške skupnosti od družbeno-gospodarskih omejitev. Trinajsti amandma in poznejša zakonodaja sta sprožila širšo razpravo o demokraciji v Združenih državah Amerike (Dewey, 1927). Kljub temu so bili Afroameričani od konca državljanske vojne do leta 1964, ko je bil sprejet zakon o državljanskih pravicah, podvrženi rasnemu sovraštvu znotraj nekaterih najpomembnejših ustanov v državi (Zinn, 2005). V Alabami in sosednjih zveznih državah je bil ta pojav še posebej izrazit (Flynt, 2004). Zakoni Jim Crow (ang. Jim Crow laws) so upočasnili proces družbeno-gospodarske integracije Afroameričanov v ameriško družbo. $Z$ raziskavo ameriške oziroma afroameriške družbe je bila poudarjena pomembnost osredotočanja na rasno problematiko, če želi država imeti demokratično prihodnost (Myrdal, 1944). Intelektualne in politične razprave o rasni segregaciji so se med letoma 1955 in 1968 prelevile v boj za državljanske pravice. Demokracija naj bi ustvarila ugodnosti, priložnosti in kulturo za vse (King, 1958). Da bi okrepili moč afroameriške skupnosti, ki je bila izključena iz razprav o demokratični prihodnosti države, so se pedagoške reforme uprle konservativni strukturi oblasti, ki je v prvi polovici 20. stoletja obvladovala politično življenje v Alabami. Ameriške človekoljubne reforme so še vse 20. stoletje imele vodilno vlogo pri širjenju demokracije. Po drugi svetovni vojni se je paradigma ameriškega reformizma spremenila: določali so jo znanstveni diskurzi, ki so temeljili na analizah in obsežnih nizih družbenih podatkov. $\mathrm{V}$ drugi polovici 20. stoletja pa sta skoraj stoletje reformističnih razprav o odnosu med raso in demokracijo $\mathrm{v} Z$ Združenih državah Amerike povzela švedska znanstvenika Alva in Gunnar Myrdal (Myrdal, 1944) ${ }^{[1]}$.

\section{Teorija}

$\mathrm{V}$ članku so preučeni konteksti in razmere, $\mathrm{v}$ katerih nastajajo načrti, ki krepijo občutek pripadnosti kraju in skupnosti. Uporabljen je interdisciplinarni pristop, preučene pa so omejitve ter možnosti načrtov in načrtovalskih strategij, ki sooblikujejo sedanjo ameriško pokrajino.

Identiteta temelji na kodificiranih okoliščinah ter tradicionalnih vrednostnih sistemih in pravilih (Deleuze in Guattari, 1972; Gleason, 1983). Kolektivna identiteta se oblikuje na presečišču različnih pogledov, kar na neki način zgodovino in spomin prisili v to, da se združita (Lee, 2010) ${ }^{[2]}$. Načrtovalci, ki jih zanima odnos med kolektivnim spominom in prostorom, se odzivajo na splošno potrebo po javnih simbolih, ki upravičujejo družbeni red (Dwyer in Alderman, 2008a: 166). Novejše raziskave spomeniških pokrajin potrjujejo osrednjo vlogo krajev pri razvoju kolektivnega spomina (Halbwachs, 1980; Nora, 1989; Wasserman, 1997). Živi spomin je jasen, pomemben in nujen zgodovinski in družbeni kritik (Hayden, 1997; Huntington, 1998). V zadnjih letih se preučujeta vloga in vrednost krajinskega oblikovanja pri ohranjanju kolektivnega spomina na zgodovinske kraje in prakse (Dwyer in Alderman, 2008b). Po navedbah Reubena Rose-Redwooda idr. (2008) zgodovinski spomin pomaga ponovno ustvariti občutek skupne identitete. Pomembnost spominskih krajev kot družbenih katalizatorjev je bila obravnavana $\mathrm{v}$ različnih raziskavah, zlasti v tistih, ki so preučevale povezavo med kolektivnim spominom in urbanim prostorom (Azaryahu in Foote, 2008; Lepore, 2010). Za znanstvenike in krajinske arhitekte so ti kolektivni simboli del regionalne kulturne identitete (Cosgrove, 1978; Jackson, 1980, Jencks, 2002). Diskurz o demokratični vrednosti odnosa med zgodovino, spominom, identiteto in skupnostjo postaja vse pomembnejši v razpravah o prihodnosti Amerike (Wood, 2011). Za načrtovalce je kolektivni spomin nekaj, kar spodbuja ukrepanje in omogoča preučevanje zgodovine (Lowenthal, 1996; Freire, 2007). Sporočilna vrednost spomina je bila jasno izražena v 30. letih 20. stoletja. Spomin je »medij tistega, kar se dogaja, « in ne »inštrument preučevanja preteklosti « (Benjamin, 2005: 576; Payne; 2007). Preteklost se v sedanjost vrne prek medija spomina, ki omogoča, da se posamično in kolektivno združita v tradicionalni krog časa (Deleuze, 1994).

V novejših raziskavah nelinearne krajinske arhitekture se poudarja prostorska razdrobljenost ameriške pokrajine (Barnett, 2000), ki je konec 20. stoletja ponujala možnost oblikovalskega eksperimentiranja (Secchi, 1989; Solà-Morales, 1995). Pokrajine so kot » mejniki, obzorja, znaki ali območja « našega spomina. Pomagajo nam priklicati spomine, ki spodbujajo nadaljnje ukrepanje (Barba Casanovas, 2010: 109). Spominjanje pa je včasih dejanje kolektivnega poguma, zlasti ko določen problem še vedno obstaja (Morrison, 1987; Assmann, 2011). Čeprav spomin na nekatere zgodovinske kraje hitro izginja, ga lahko zdaj obravnavamo bolje kot v preteklosti (Tuan, 2001; Evans, 2011). To omogoča krepitev lokalne identitete in občutka pripadnosti skupnosti (Sandage, 1993; Erll, 1999). Pojem kolektivnega spomina lahko uporabimo za zagovarjanje in uveljavitev določene identitete $\mathrm{v}$ primerjavi $\mathrm{z}$ identiteto druge 
skupine (Nora, 1989; Hoelscher in Alderman, 2004). Analiza, predstavljena v članku, kaže, kako in v kolikšni meri oblikovalske prakse vplivajo na krepitev lokalne identitete.

\section{Metodologija}

Članek temelji na analizi afroameriških zgodovinskih krajev (preglednica 1). Zaradi geografskih in zgodovinskih razlogov je raziskava omejena na Alabamo. V njej se preučujejo načrti in načrtovalske strategij, ki so bili razviti za oblikovanje afroameriške spomeniške pokrajine, prikazuje pa tudi njeno splošno stanje. Temelji na primarnih in sekundarnih virih in vidnem gradivu, kot so fotografije krajev, ki smo jih obiskali. $V$ članku so prav tako upoštevana načrtovalska poročila in pogovori z lokalnimi prebivalci, znanstveniki, strokovnjaki, študenti, upravniki in vodji skupnosti. Posredno gradivo, ki smo ga uporabili v raziskavi, vsebuje knjige in članke. Uporabili smo deduktivni raziskovalni pristop, ki je odvisen od konteksta (slika 1). Posebej smo analizirali muzej državljanskih pravic v Montgomeryju, in sicer zaradi njegovega prispevka

Preglednica 1: Muzeji in spomeniki afroameriške zgodovine v Alabami in njeni okolici med letoma 1974 in 2011

\begin{tabular}{|c|c|c|}
\hline Vrsta (številka slike) & Spomenik in lokacija & Ustanovljen \\
\hline cerkev & $\begin{array}{l}\text { baptistična cerkev, posvečena Martinu Luthru Kingu, na aveniji Dexter, } \\
\text { Montgomery, Alabama }\end{array}$ & 1974 \\
\hline muzej in park $(17 a, 17 b)$ & $\begin{array}{l}\text { zgodovinski kraj nacionalnega pomena, posvečen Martinu Luthru } \\
\text { Kingu (ang. MLK National Historic Site), Atlanta, Georgia }\end{array}$ & 1976 \\
\hline spominski kip & kip Martina Luthra Kinga z napisom »I Had A Dream«, Selma, Alabama & 1979 \\
\hline muzej & $\begin{array}{l}\text { muzej župnišča Dexter (ang. Dexter Parsonage Museum), Montgomery, } \\
\text { Alabama }\end{array}$ & 1982 \\
\hline spomenik (11a) & $\begin{array}{l}\text { spomenik žrtvam gibanja za državljanske pravice (ang. Civil Rights Memorial), Montgo- } \\
\text { mery, Alabama }\end{array}$ & 1989 \\
\hline spominska stavba & $\begin{array}{l}\text { nacionalni muzej za državljanske pravice (ang. National Civil Rights Museum), } \\
\text { Memphis, Tennessee }\end{array}$ & 1991 \\
\hline $\operatorname{trg}(8 b, 9 a, 9 b)$ & park Kelly Ingram, Birmingham, Alabama & $1992^{*}$ \\
\hline muzej in arhiv (8a) & inštitut za državljanske pravice, Birmingham, Alabama & $1992^{*}$ \\
\hline muzej & $\begin{array}{l}\text { džezovska dvorana slave v Alabami (ang. Alabama Jazz Hall of Fame), } \\
\text { Birmingham, Alabama }\end{array}$ & 1993 \\
\hline spominska stavba & nacionalni muzej in inštitut za volilne pravice, Selma, Alabama & 1993 \\
\hline spominski most & most Edmunda Winstona Pettusa, Selma, Alabama & $1996^{* *}$ \\
\hline muzej (11b) & muzej Rose Parks, univerza Troy, Montgomery, Alabama & 2000 \\
\hline muzej & središče za državljanke pravice, Montgomery, Alabama & 2005 \\
\hline spominski pločnik & spominski pločnik Jamesa Reeba, Selma, Alabama & 2005 \\
\hline kip (16) & spomenik Erskina Hawkinsa, Birmingham, Alabama & 2006 \\
\hline muzej & središče za ozaveščanje o nacionalni dediščini okrožja Lowndes, Hayneville, Alabama & $2006^{* *}$ \\
\hline spominska stavba (10) & Belcherjeva in Nixonova stavba (ang. Belcher-Nixon Building), Birmingham, Alabama & 2009 \\
\hline park (14a, 14b) & park Louisa Armstronga, New Orleans, Louisiana & 2010 \\
\hline kip (15c) & spomenik plesalcem bambuole, New Orleans, Louisiana & 2010 \\
\hline $\operatorname{trg}(15 a)$ & trg Congo, New Orleans, Louisiana & 2010 \\
\hline medijska knjižnica (2b) & rosenwaldska šola na ulici Shiloh, Notasulga, Alabama & 2010 \\
\hline muzej in park & spominski muzej Jesseja Owensa, Oakville, Alabama & 2010 \\
\hline muzej (7) & varna hiša Martina Luthra Kinga ml., Greensboro, Alabama & 2011 \\
\hline spomenik na pokopališču (12a) & predel Africatown na metropolitanskem območju mesta Mobile, Alabama & 2011 \\
\hline spominska stavba & $\begin{array}{l}\text { muzej gibanja svobodnih vozačev (ang. Freedom Rides Museum), } \\
\text { Montgomery, Alabama }\end{array}$ & 2011 \\
\hline park & park Martina Luthra Kinga ml., Auburn, Alabama & 2011 \\
\hline
\end{tabular}

Opomba: (*) Okrožje, posvečeno gibanju za državljanske pravice v Birminghamu, Alabama; $\left({ }^{*}\right)$ most Edmunda Winstona Pettusa in spominski center v okrožju Lowndes sta del zgodovinske poti iz Selme v Montgomery, ki jo je leta 1996 ameriški kongres razglasil v spomin na pohod za volilne pravice v Alabami leta 1965. 
$\mathrm{k}$ izboljšanju sloga njegovih spomeniških in umetniških prvin. V raziskavi so obravnavani tudi New Orleans, Atlanta in Memphis. Primer urbanizacije afroameriškega spomenika v Alabami se osredotoča na analizo spomenikov v mestih Birmingham, Montgomery in Mobile. $V$ članku so na podlagi terenskih zapiskov in izsledkov terenske raziskave analizirane intelektualne razmere, $\mathrm{v}$ katerih je bil spomenik oblikovan, njegova funkcija, sporočilo, ki ga prinaša, odnos z drugimi tipološko podobnimi deli in splošni namen njegovega načrtovalca. Terenska raziskava je bila opravljena poleti in jeseni leta 2011 v šestih alabamskih okrožjih, ki spadajo v območje Črnega pasu: Macon, Dallas, Hale, Mobile, Montgomery in Jefferson. Z njo smo preučili življenje in prostor tradicionalne afroameriške skupnosti v Alabami. Raziskava bo uporabna za zgodovinarje in oblikovalce, kot tudi za vse druge, ki jih zanima vloga spomina pri ohranjanju zgodovine.

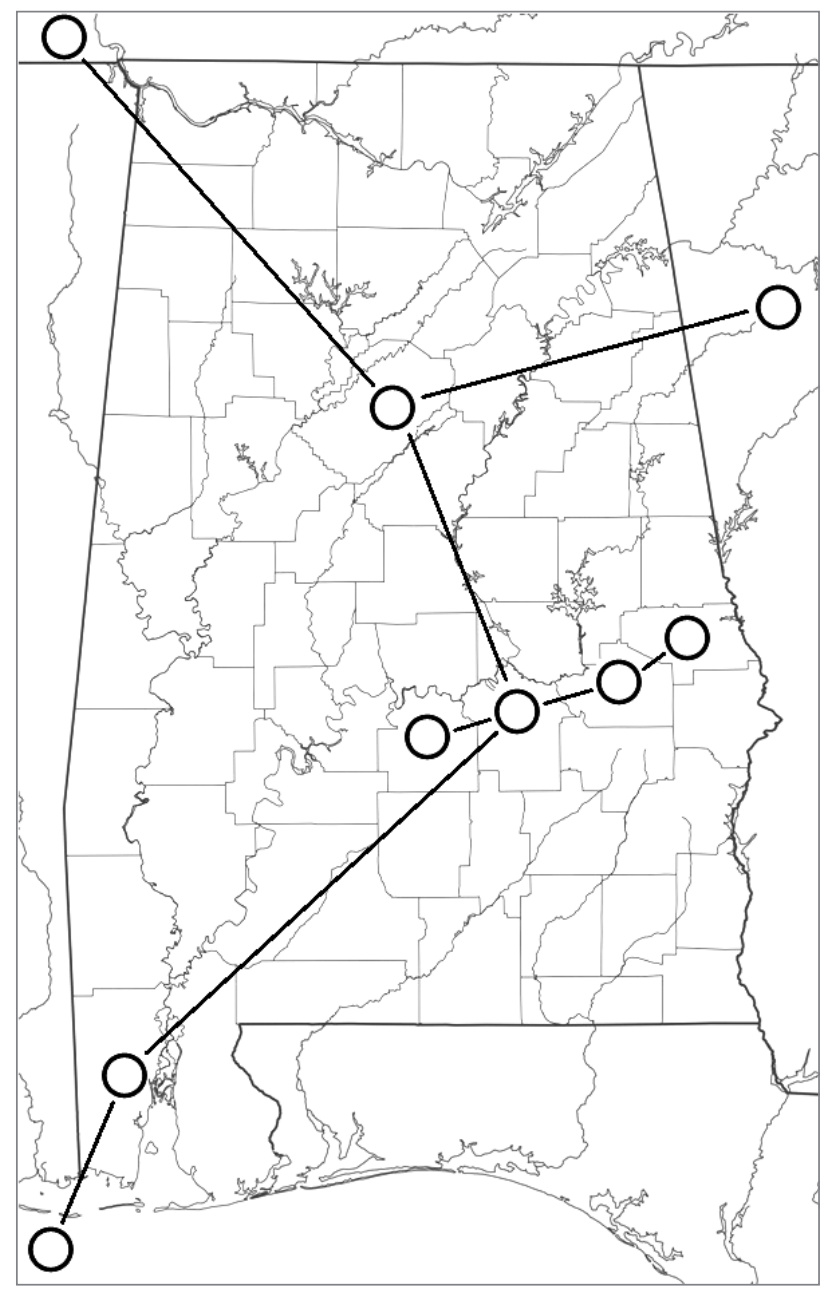

Slika 1: Afroameriški zgodovinski kraji. Od leve proti desni: New Orleans, Mobile (spodaj); Selma, Montgomery, Tuskegee, Auburn (na sredi); Memphis, Birmingham, Atlanta (zgoraj; ilustracije: Marco Giliberti).

\section{Afroameriški spomeniki v Alabami 4.1 Spomeniki na alabamskem podeželju}

Terenska raziskava je bila opravljena $\mathrm{v}$ treh alabamskih okrožjih, ki spadajo na območje Črnega pasu: Macon, Hale in Dallas. V 30. letih 20. stoletja je družbeno in politično življenje Afroameričanov v okrožju Macon zaznamovala segregacija šolskega sistema. Prve poskuse šolske reforme je v 20. in 30. letih 20. stoletja izpeljal industrijec in človekoljub Julius Rosenwald (1862-1932) v okviru programa gradnje podeželskih šol (ang. Rural Schools Building Program, v nadaljevanju: RRSBP). Šlo je za reformo posodobitve šolskega sistema, ki je spodbujala socialno vključevanje vseh šoloobveznih otrok, tudi tistih iz revnih afroameriških družin. Rosenwald je RRSBP podpiral in financiral skupaj z Bookerjem T. Washingtonom (1856-1915), afroameriškim pisateljem in predsednikom inštituta Tuskegee. Rosenwald in Washington sta zasnovala program izboljšav izobraževalnega sistema na regionalni ravni, v sklopu katerega je bilo po vsem jugu ZDA zgrajeno veliko mestnih in predmestnih šol (slika 2a). Pred kratkim je bila ena teh zgodovinskih šol tudi glavna tema ameriške raziskave (Dyer in Bailey, 2008; slika 2b).
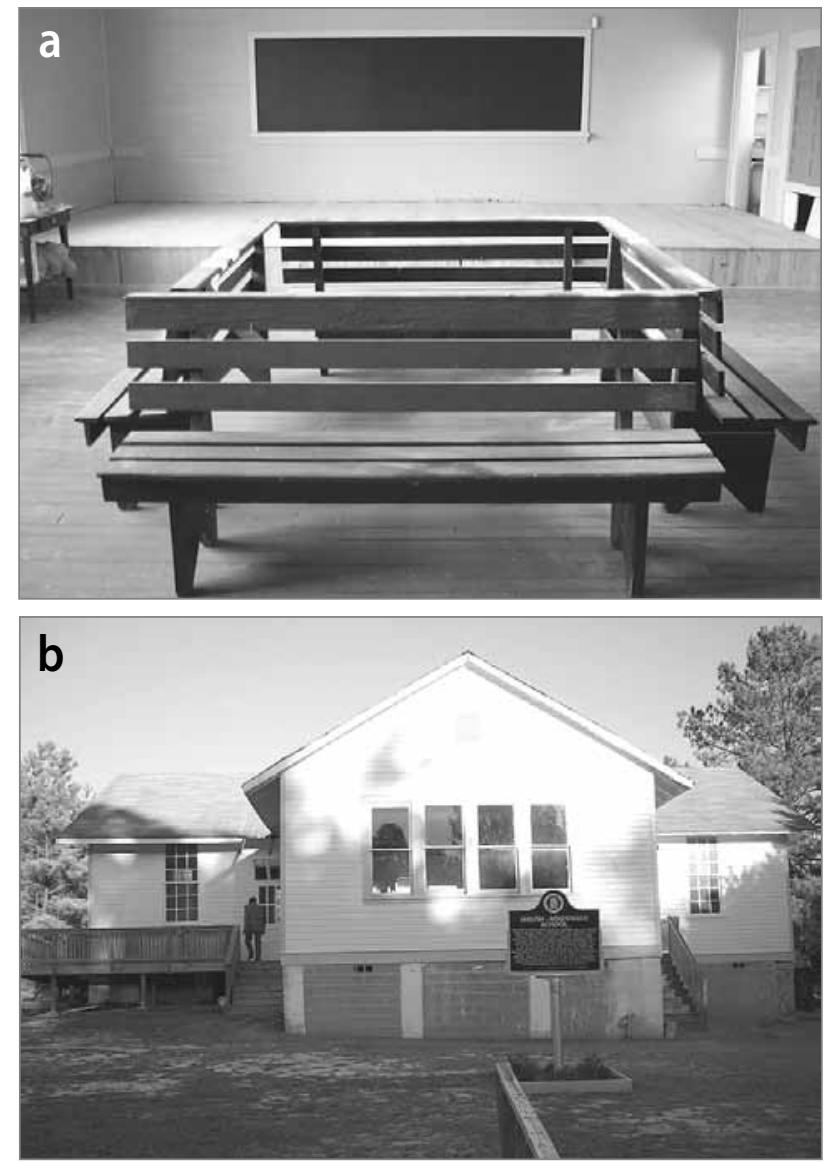

Slika 2: (a) Notranjost rosenwaldske šole v Notasulgi v Alabami. Izvirne šolske klopi (spredaj), tabla in oder (zadaj); (b) rosenwaldska šola, zgrajena v podeželski Notasulgi v alabamskem okrožju Macon. Pogled na obnovljeno pročelje (foto: Marco Giliberti). 

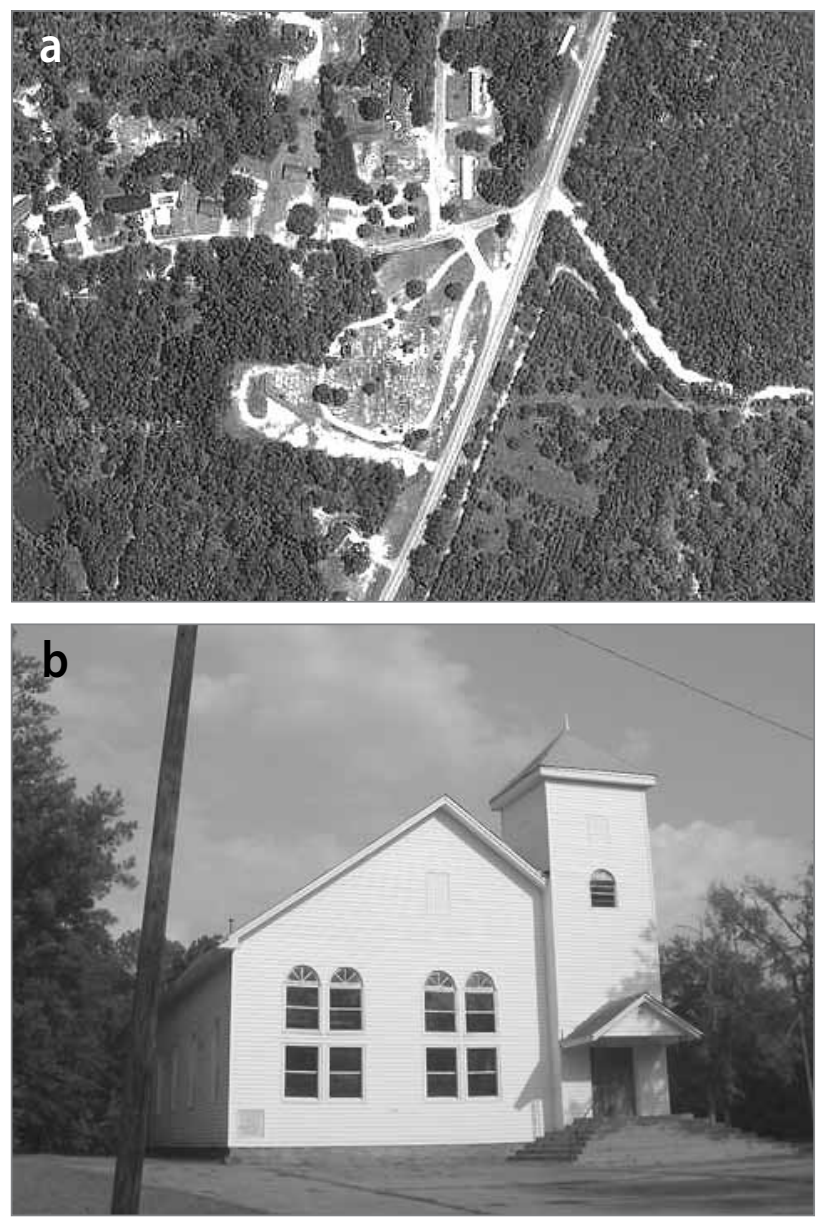

Slika 3: (a) Pokopališče metodistične baptistične cerkve na ulici Shiloh $v$ Notasulgi, ki je tipičen primer podeželskega afroameriškega pokopališča v Alabami; b) metodistična baptistična cerkev na ulici Shiloh je sedež metodistične baptistične afroameriške skupnosti $v$ podeželski vasi Notasulga ((a) vir: zemljevidi Google, 2013; (b) foto: Marco Giliberti).

V okrožju Macon je zgodovinska rosenwaldska šola pritegnila pozornost, ko je Liz Sims promovirala rojstvo fundacije za obnovo skupnosti na območju ulice Shiloh (slika 3a). Na začetku so pri projektu prostovoljno sodelovale različne lokalne izobraževalne ustanove. Strokovnjaki in učitelji z univerze v Auburnu so prispevali svoj čas in znanje ter so bili pripravljeni nadaljevati sodelovanje s fundacijo v okrožju Macon. Prav tako so pomagali zgraditi novo računalniško sobo $\mathrm{v}$ prizidku šole. $\mathrm{V}$ okolici šole prevladujejo velika drevesa z bogatimi krošnjami, ki nudijo senco (hrasti, bresti in hikoriii), in vzpenjalke (kudzu), s katerimi je preraščena zgodovinska podeželska pokrajina zgodnjega 20. stoletja. Iz te pokrajine se dviga podeželska cerkev (slika 3b), v kateri je potekala raziskava sifilisa v mestu Tuskegee (Reverby, 2001).

Raziskava sifilisa v Tuskegeeju je bila klinična študija, ki jo je med letoma 1932 in 1972 izvajal ameriški inštitut za javno zdravje (ang. U.S. Public Health Service, v nadaljevanju: USPHS). Kršila je etična načela, saj je na 399 Afroameričanih
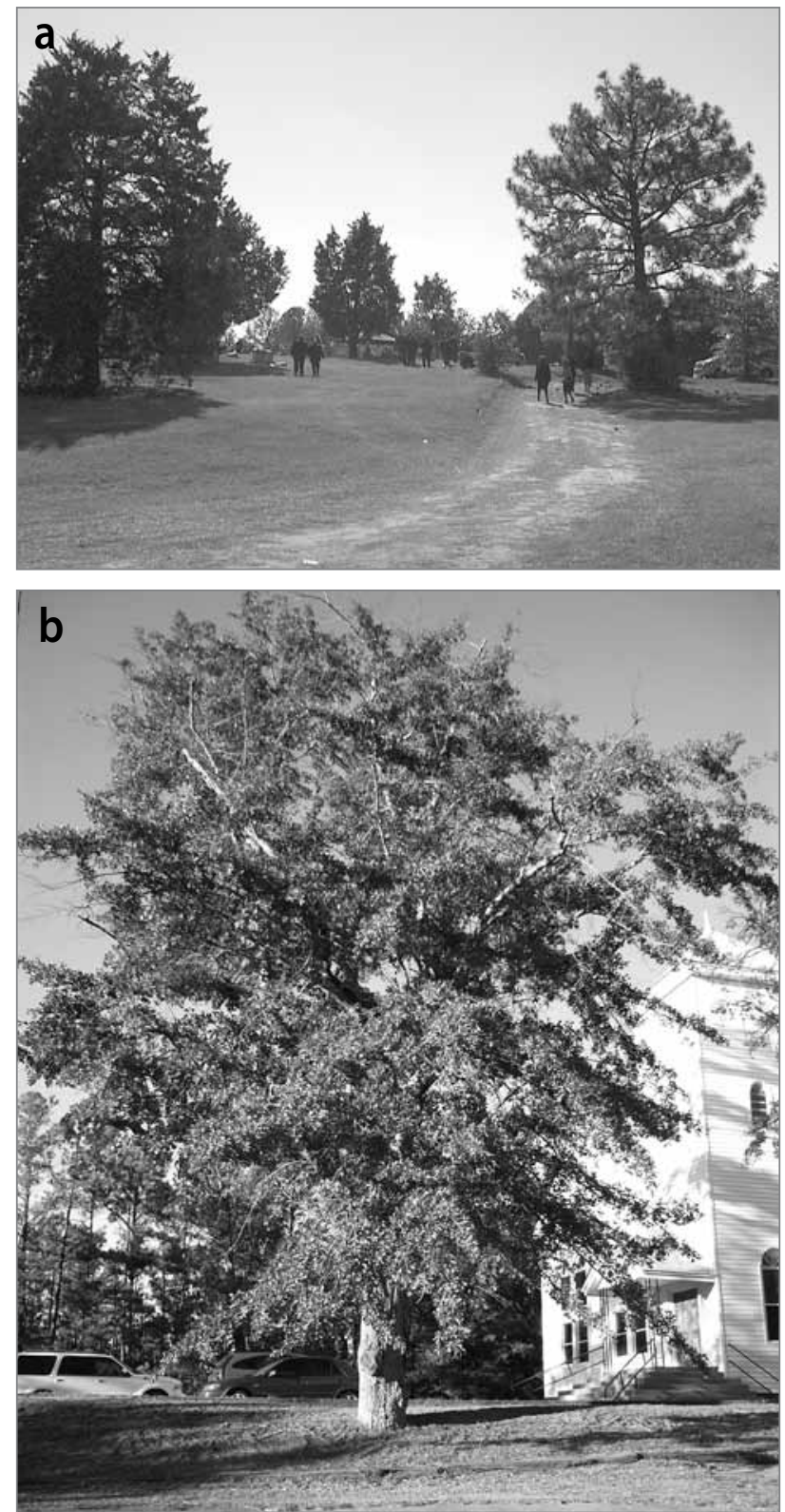

Slika 4: (a) Pokopališče metodistične baptistične cerkve na ulici Shiloh v Notasulgi, na katerem je pokopano največ žrtev raziskave sifilisa. Večina jih je prihajala iz Notasulge; (b) to drevo je simbol kolektivnega spomina na raziskavo sifilisa v Tuskegeeju. Označuje mesto, na katerem so bolniki s sifilisom stali in čakali na zdravljenje (foto: Marco Giliberti).

preučevala naravni potek sifilisa, ne da bi jih zdravila. Veliko udeležencev te študije je prihajalo iz okrožja Macon. Na sliki 4a je prikazano pokopališce, na katerem so bili mnogi pokopani. Leta 2000 je bilo na univerzi Tuskegee v okrožju Macon ustanovljeno prvo središče za bioetiko Afroameričanov. Projekt financira ameriška vlada, ki se želi s tem opravičiti udeležencem študije in njihovim potomcem za vse, kar so zaradi te študije pretrpeli (Jones, 1993; Gray, 1998; Sims, 2009). Zadnja leta pa so bile vladne politike, kot je ustanovitev središča za bioetiko na univerzi Tuskegee, deležne kritik. L. Sims (2009) se je pritoževala, da institucionalni ukrep ni zadovoljil priča- 

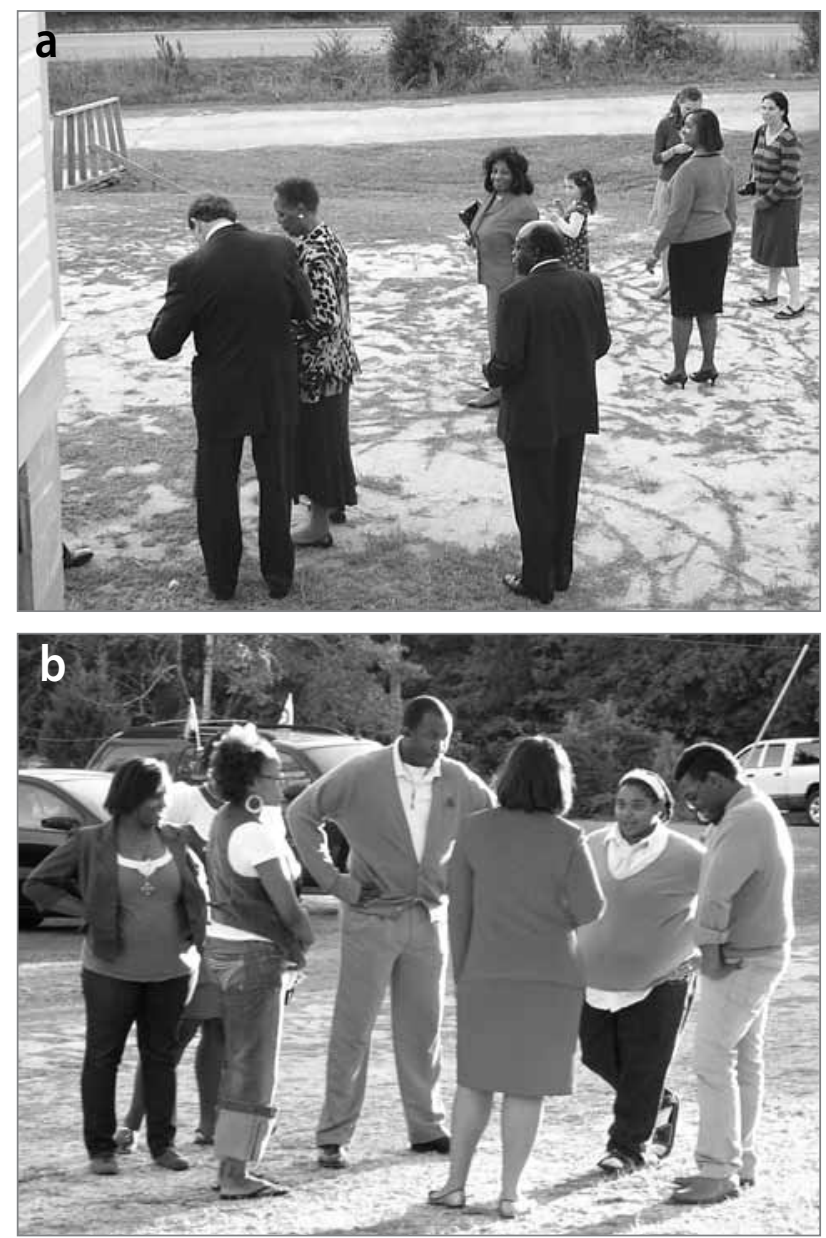

Slika 5: (a) Shiloh v Notasulgi. Vodja afroameriške skupnosti Liz Sims z uradnikom iz nacionalnega registra zgodovinskih krajev; (b) člani pevskega zbora iz Tuskegeeja v metodistični baptistični šoli v Shilohu v Notasulgi pred nastopom na pogrebu (foto: Marco Giliberti).

kovanj skupnosti in da je bila univerza Tuskagee za sosednjo afroameriško skupnost v Notasulgi vedno kraj, ki je bil zgodovinsko, kulturno in moralno ločen od nje (Ware, 2011). Namesto tega središča je bolj cenila drevo, ki so ga posadili v bližini rosenwaldske šole v Shilohu, ki naj bi bilo po njenem simbol, ki bi lahko ohranjal kolektivni spomin na študijo sifflisa med prihodnjimi generacijami Afroameričanov (slika 4b). Afroameriška skupnost v Notasulgi jemlje spomin na to drevo zelo resno. Spomin nanj se časti in se na splošno razume kot simbol obnavljanja identitete. Po lokalnem ustnem izročilu je v 70. letih 20. stoletja krošnja drevesa Afroameričanom, ki niso vedeli, da imajo sifilis, in so čakali na zdravljenje, nudila senco pred vročim poletnim soncem. Podoba teh čakajočih ljudi je osrednje sporočilo oblikovalske prakse. $V$ tem konkretnem primeru oblikovanje zapletene in slojevite spomeniške pokrajine ponuja priložnost za oblikovanje prostora, v katerem lahko stare in nove prakse sobivajo (Giliberti, 2011; sliki 5a in 5b).

Okrožje Dallas je zasedalo strateški položaj v regionalni trgovini z bombažem, ki je temeljila na rečnem transportu, in je imelo

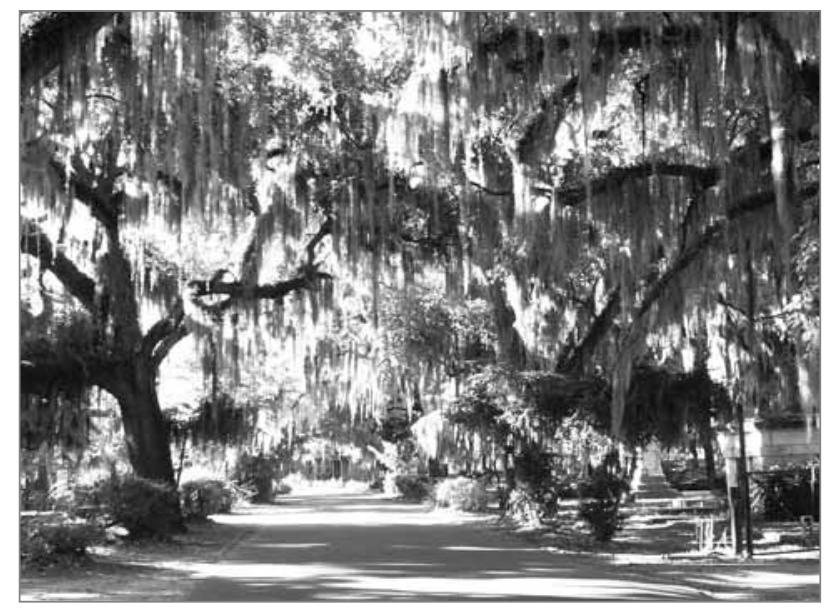

Slika 6: Staro pokopališče v Selmi. Španski mah je cvetoča parazitska rastlina, ki pogosto raste na velikih drevesih na jugu ZDA, kot so ciprese in zimzeleni hrasti (foto: Marco Giliberti).

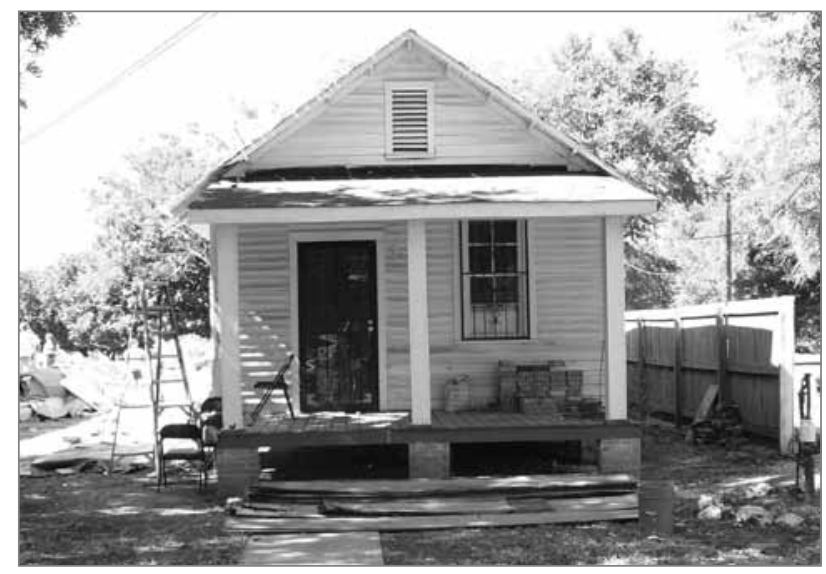

Slika 7: Novi muzej črnske zgodovine Varna hiša v alabamskem okrožju Hale, posvečen Martinu Luthru Kingu ml. (foto: Marco Giliberti).

leta 1965 pomembno vlogo med pohodom za državljanske pravice od Selme do Montgomeryja. Mesto Selma leži na bregovih reke Alabame, čez katero se razteza most Edmunda Pettusa, na katerem se je v 60. letih 20. stoletja zgodil osrednji dogodek v afroameriškem boju za volilne pravice. Urad za ohranitev zgodovinskih krajev v Selmi je predpisal, naj se spomeniki na tem območju (zlasti muzej in inštitut za volilne pravice, ustanovljen leta 1993, muzej suženjstva in državljanske vojne, ustanovljen leta 2002, in spominski pločnik Jeffa Reeba, urejen leta 2005) zgradijo skupaj s projektom obnove hotela Saint James in stare trgovske ulice Water Avenue v starem delu mesta. Načrtovalci in upravljavci so sprejeli ohranitvene strategije, da bi v mesto pritegnili turiste. Kljub temu staro afroameriško pokopališ̌ce ostaja glavni kulturni spomenik v mestu (slika 6).

Prebivalci okrožja Hale na jugovzhodu Alabame so pomagali zgraditi nov muzej črnske zgodovine Varna hiša (ang. Safe House Black Historic Museum) v mestu Greensboro (slika 7). Zgodovinski pomen te stavbe je povezan $\mathrm{z}$ dogodkom $\mathrm{v}$ zadnjem obdobju življenja Martina Luthra Kinga ml. Muzej obuja spo- 

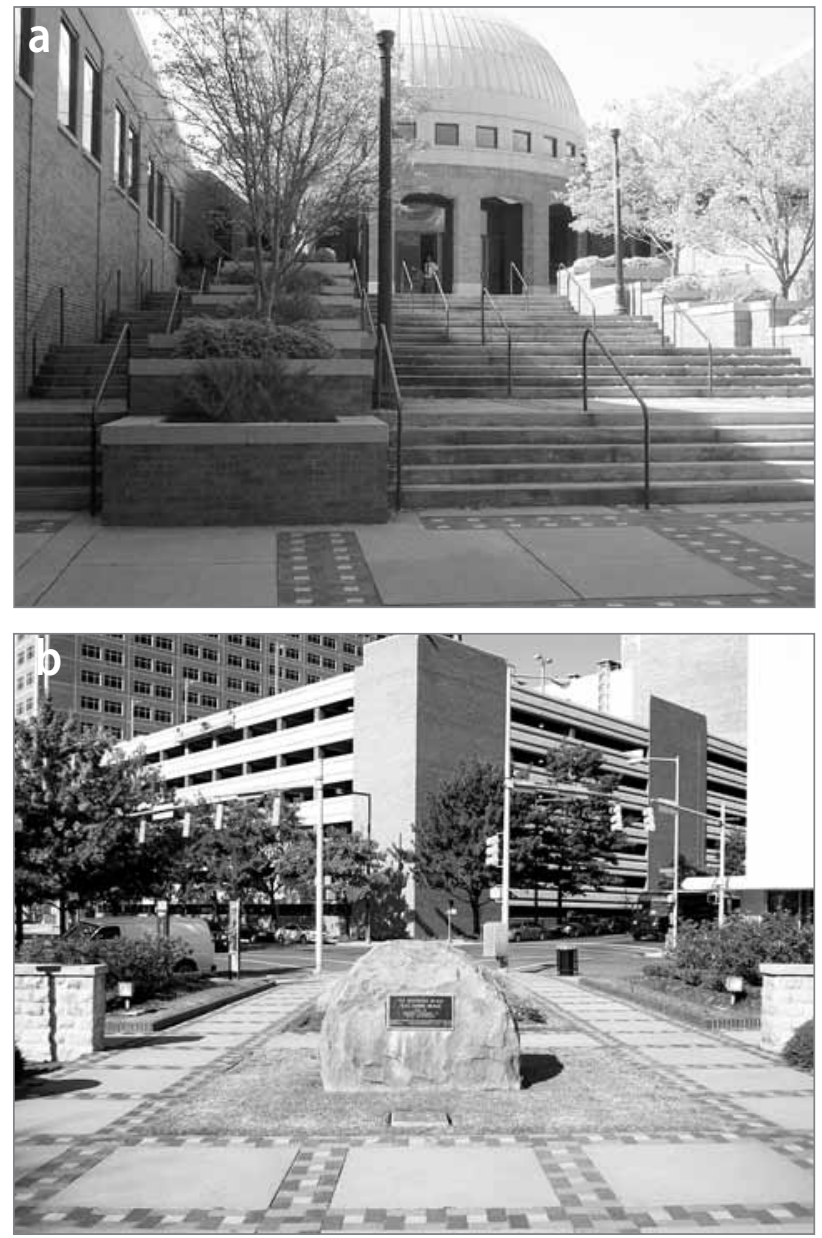

Slika 8: (a) Inštitut za državljanske pravice v birminghamskem predelu, posvečenem državljanskim pravicam. V okrožju sta tudi alabamska džezovska dvorana slave in baptistična cerkev na 16. ulici; (b) spominski park Kellyja Ingrama ( $v$ istem predelu); pogled iz parka (foto: Marco Giliberti).

min na ikonsko podobo »varne hiše «, ki med turisti vzbuja občutek empatije. $V$ tem primeru je načrtovalcem uspelo čustveno povezati zgodovino in spomin. Martin Luther King se je v to hišo zatekel, ko je bežal pred kukluksklanom. Muzej ohranja simbolični občutek napetosti in negotovosti, ki ga je King doživljal med svojim bivanjem v Greensboru leta 1968. $\mathrm{V}$ tem primeru so oblikovalci uporabili hagiografski slog retorike, ki pomaga krepiti že tako močno čustveno povezavo, ki jo obiskovalec občuti na tem kraju. Razlog za obstoj muzeja izhaja iz podeželske okolice, $v$ kateri živijo revne afroameriške družine. Okrožja Macon, Hale in Dallas poosebljajo afroameriško spomeniško pokrajino na alabamskem podeželju.

\subsection{Spomeniki v alabamskih mestih}

Drugi val selitev v mesta se je v Alabami začel po koncu državljanske vojne. Birmingham je najstarejše industrijsko mesto v okrožju Jefferson. Industrijsko načrtovanje, ki ga je financiral zasebni kapital, je oblikovalo geografsko podobo mesta v 20. stoletju. Paternalizem kapitala je krepil politični
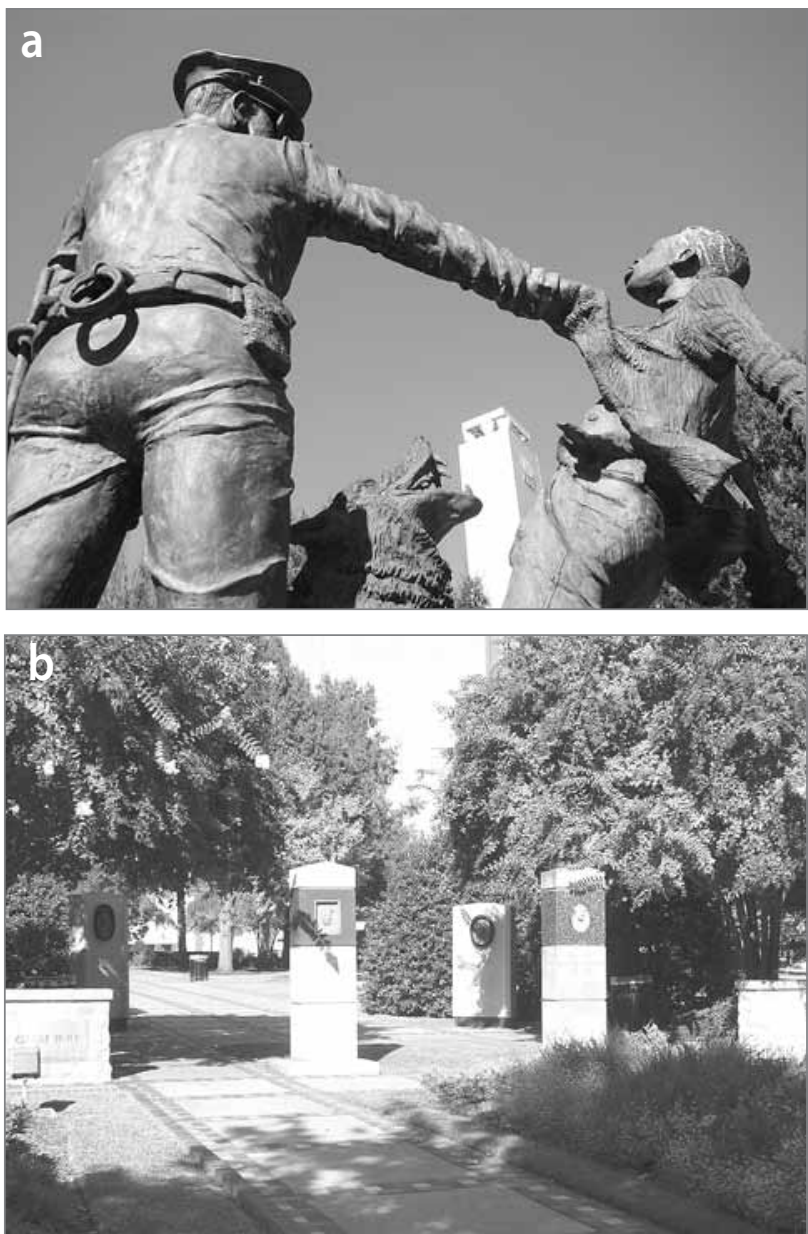

Slika 9: (a) Kip v spominskem parku Kellyja Ingrama v birminghamskem predelu, posvečenem državljanskim pravicam; (b) vhod v spominski park Kellyja Ingrama (foto: Marco Giliberti).

in ekonomski optimizem nižjih družbenih razredov. $\mathrm{V}$ drugi polovici 20. stoletja pa so začela mesta v Alabami počasi, vendar vztrajno propadati. Ne politiki ne upravljavci niso uspeli zajeziti fizičnega propadanja in rasnih trenj v mestih. $\mathrm{V}$ drugi polovici 20. stoletja so se morali oblikovalci zaradi krepitve gibanja za državljanske pravice in njegovega hitrega širjenja soočiti z novimi problemi in razviti nove disciplinske paradigme, ki so učinkovale v hitro spreminjajoči se družbi (King, 1958). Nastajajoče družbeno-politične razmere so take nudile priložnost za oblikovalsko eksperimentiranje (Sandage, 1993; Blair in Neil, 2000; Assmann, 2011). Tema spomenika je poudarila potrebo po preučevanju (Blair in Neil, 2000). Ker zaseda Montgomery pomembno mesto v kolektivnem spominu na boj za državljanske pravice v 50. in 60. letih ter na koncu 20. stoletja, je tamkajšnji muzej državljanskih pravic postal nova paradigma spomeniškega oblikovanja (Connerly, 2005; Boyer, 2011). Novost $\mathrm{v}$ afroameriški spomeniški pokrajini je mesto Mobile, ki je med najstarejšimi pristanišči v Mehiškem zalivu. Pred ameriškim nakupom Louisiane leta 1803 je bilo najpomembnejše pristanišče trgovine s sužnji, zaradi česar je 
imelo pomembno vlogo v zgodovini suženjstva v ZDA. Spomeniška pokrajina mesta je bila odkrita pred krakim, potem ko je ameriška romanopiska Sylviane Diouf objavila zgodbo o zadnji suženjski ladji, ki je potovala v ZDA. Leta 1860 je v Mobile prispelo veliko število Afričanov, ki so tam ustanovili afriško vas (Diouf, 2007).

Inštitut za državljanske pravice v Birminghamu (sliki $8 \mathrm{a}$ in $8 \mathrm{~b}$ ) se nahaja v predelu, ki je posvečen državljanskim pravicam in zajema še spominski park Kellyja Ingrama, alabamsko džezovsko dvorano slave in baptistično cerkev na 16. ulici (ang. 16th Street Baptist Church; Gallagher, 1999). Na sliki 9a je prikazan kip v spominskem parku Kellyja Ingrama. Kipar zavrača in obsoja institucionalno nasilje, ki ga je policija izvajala nad afroameriškimi protestniki v njihovem boju za boljš̌ možnosti in več državljanskih pravic. Tema spominskega parka je javna pritožba zoper represivne policijske metode in njihove posledice (slika 9b). Za skulpture v tem parku je značilen močan realizem, ki temelji na ikonografskem repertoarju fotografske resničnosti (Dekel, 2009). Skulpture v parku so dinamične in izražajo pereče dogodke iz 60. let 20. stoletja. Dinamično dogajanje, ki ga prikazuje kipar, je zamrznjeno v trenutku boja za svobodo. Skulpture so prežete s populistično retoriko in po eni strani dramatizirajo dejstva, po drugi pa ponujajo razlago resničnosti, ki je odkrito čustvena, medtem ko je pripovedni ton epski in ne zgodovinski.

Križǐšce Tuxedo (ang. Tuxedo Junction) je nekaj kilometrov oddaljeno od spominskega parka Kellyja Ingrama in je pomembno afroameriško zgodovinsko območje v birminghamskem predmestju Bessemer. V 20. letih 20. stoletja je nočno življenje Afroameričanov na križišč Dvajsete ceste in avenije Ensley cvetelo na račun džeza. $\mathrm{V}$ drugem nadstropju dvorane v trikotni stavbi iz rdeče opeke (slika 10) je Erskine Hawkins, domačin iz Birminghama, vodil posebno, živahno glasbeno sceno. Džezovska glasba je začela postajati posebna značilnost tega območja. Pesem z naslovom Tuxedo Junction, ki jo je leta 1939 napisal Hawkins, izvajal pa Glen Miller, je bila izredno priljubljena in vir ponosa za vse, ki so si prizadevali za glasbeno oživitev mesta (Connerly, 2005). Danes je križišče Tuxedo eden od zgodovinskih spomenikov v Birminghamu. Stavba stoji na istem mestu kot pred šestdesetimi leti, napis na njej pa obvešča o njeni zgodovinski vrednosti. $\mathrm{Z}$ ustrezne razdalje lahko občudujemo posebnost tega zgodovinskega objekta, saj dobimo občutek, da je odtujen od tamkajšnje mestne pokrajine, nad katero se zdaj dviga prodajalna Honde.

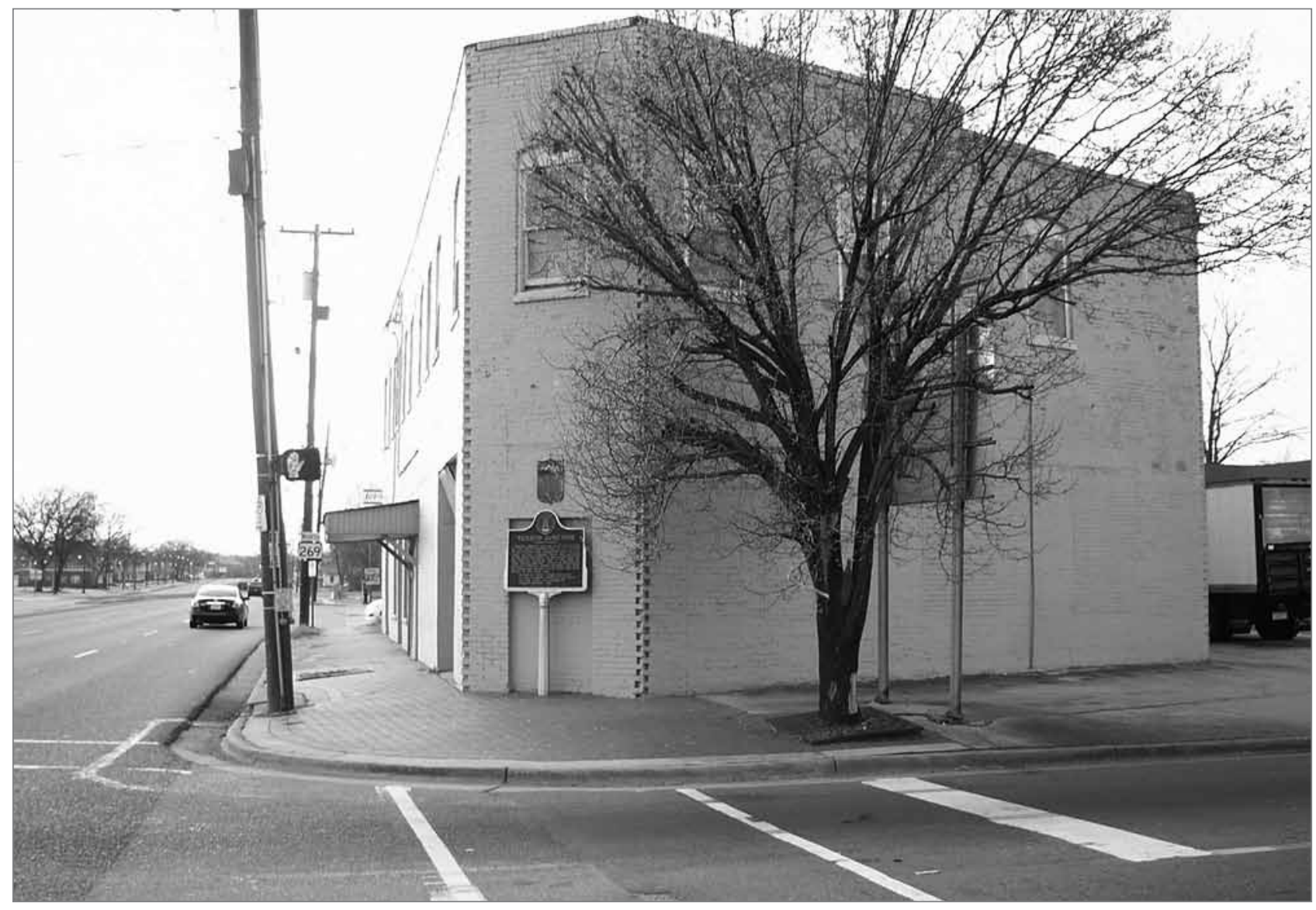

Slika 10: Križišče Tuxedo, zgodovinski afroameriški kraj v predmestju Bessemer v birminghamskem metropolitanskem območju (foto: Marco Giliberti) 

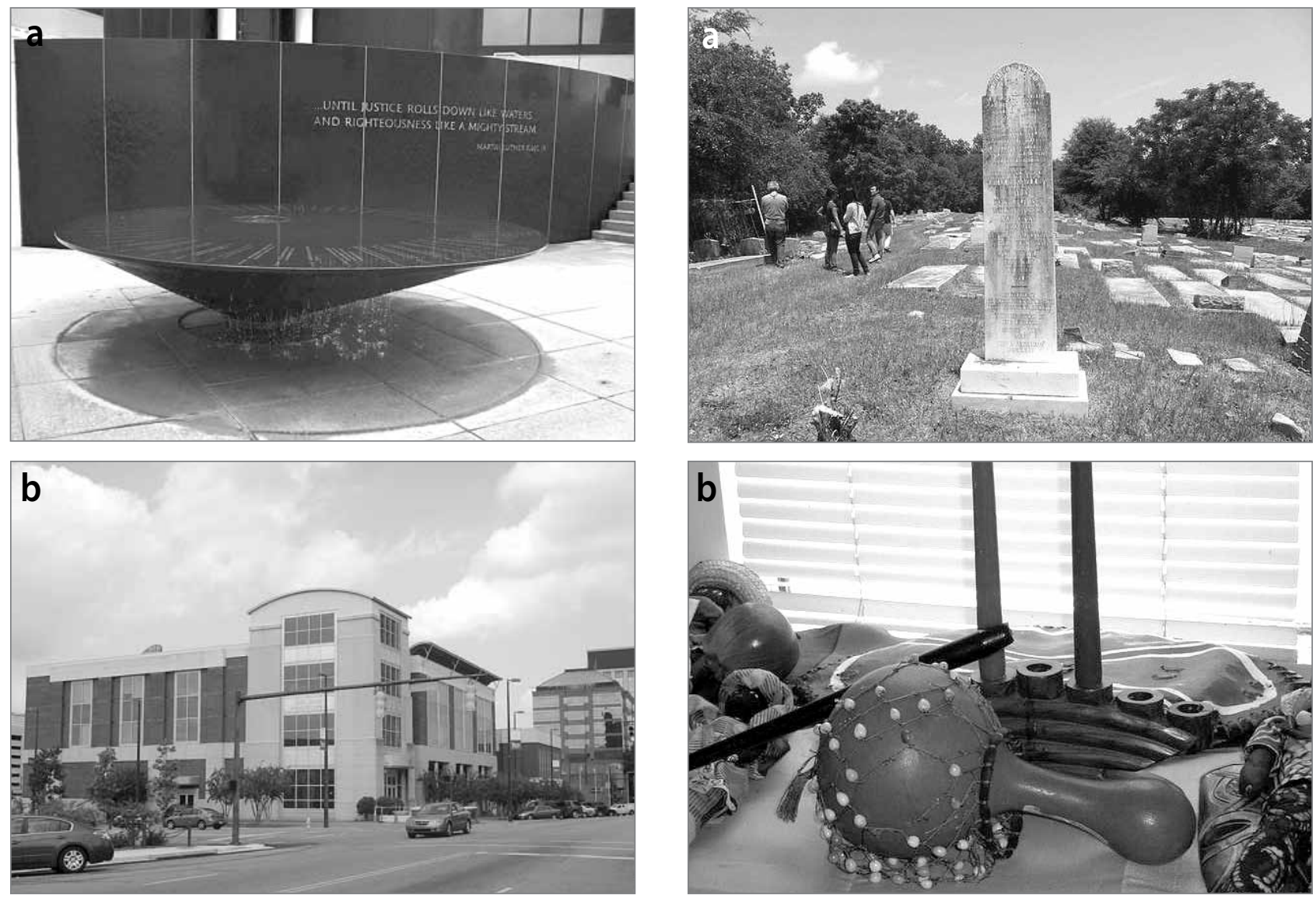

Slika 11: (a) Spomenik boju za državljanske pravice v Montgomeryju je bil postavljen $v$ okviru načrta obnovitve $z$ več predvidenimi ukrepi za preoblikovanje mestnega tkiva; (b) leta 1990 je univerza Troy v Montgomeryju ustanovila Muzej Rose Parks (foto: Marco Giliberti).

Slika 12: (a) Od zgodovinskega kraja Africatown sta ostala samo še pokopališče in spomenik; (b) predmeti, ki dokazujejo, da so v Africatownu nekoč živeli sužnji. Nekatera glasbila so zdaj na ogled v majhnem muzeju (foto: Susan Godwin).

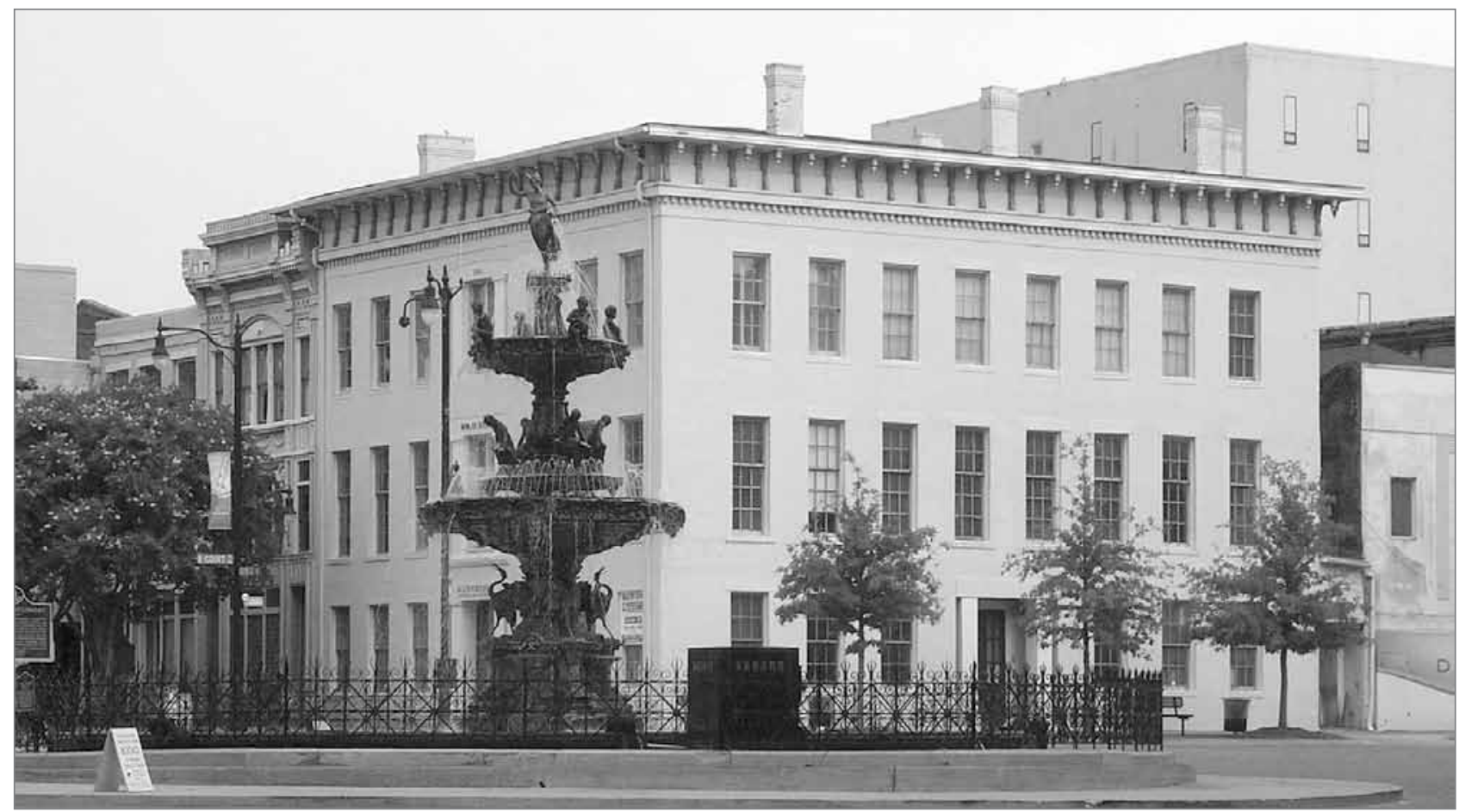

Slika 13: Po več desetletjih sprememb je bil kraj, ki se je v preteklosti uporabljal za trgovino s sužnji, preoblikovan v glavni trg v Montgomeryju (foto: Marco Giliberti). 
Spomenik boju za državljanske pravice v Montgomeryju je bil postavljen v okviru načrta obnovitve, ki je predvidel vrsto ukrepov za preoblikovanje mestnega tkiva (slika 11a). Spomenik je bil postavljen leta 1989 in zasnovan kot glavni spomenik območja (Abramson, 1996; Dwyer in Alderman, 2008b). Rosa Parks je bila med prvimi aktivisti, ki so se borili proti segregaciji in je tako imela pomembno vlogo v boju za državljanske pravice. Leta 1990 je univerza Troy v Montgomeryju ustanovila muzej boja za državljanske pravice in ga poimenovala Muzej Rose Parks (slika 11b). V okrožju Mobile je bila skupnost v predelu Africatown še ena skupnost osvobojenih afriških sužnjev, ki so našli zatočišče v močvirnatem rokavu reke Mobile. Majhna skupnost je sanjala o vrnitvi v Afriko ter se je zato močno trudila ohraniti svojo afriško dediščino in identiteto $\mathrm{v}$ Mobilu (Diouf, 2007). Potem ko so Africatown začeli zapuščati njegovi prebivalci, je začel propadati, vendar je spomin nanj ostal živ vse do današnjih dni. Danes je od njega ostalo samo še pokopališče (slika 12a). Nekaj predmetov iz vsakdanjega življenja v Africatownu je zdaj na ogled v majhnem objektu zraven pokopališča (slika 12b).

\section{Nastajajoča ameriška pokrajina?}

Po bojih za državljanske pravice je mesto Montgomery zasedlo pomembno mesto v zgodovini mestnih območij Črnega pasu. Povezave med načrtovanjem in zgodovino Afroameričanov se kažejo tudi v ustanovitvi tamkajšnjega muzeja državljanskih pravic leta 1989. Ta novi spomenik, ki ga je zasnovala slavna ameriška krajinska arhitektka Maya Lin, je sprožil razpravo o spomeniški pokrajini Afroameričanov in njeni prihodnosti. Razprava še vedno poteka, vendar zdaj vse manj Afroameričanov skrbi za te spomenike, zaradi česar se vse bolj opuščajo. Posledice so vidne v okrožjih, kot so Macon, Hale, Dallas, Jefferson, Mobile in Montgomery, ki smo jih izbrali, da bi prikazali, kako lahko trenutna razdrobljenost zgodovinske afroameriške pokrajine vpliva na oblikovalske odločitve zaščitnikov spomenikov.

Po M. Lin je spomenik prostor in ne samo predmet (Krauss, 1979). Na podlagi te domneve lahko načrtovalci spomenik razumejo kot obsežno množico odnosov med različnimi zgodovinskimi kraji, vendar ta cilj trenutno še ni popolnoma dosežen. Zdajšnji mestni trgi so bili v 19. stoletju prostor, na katerih je potekala glavnina trgovine s sužnji (slika 13), zato jih lahko povežemo z novejšo mrežo mestnih muzejev afroameriške zgodovine. Nekaj podobnega lahko vidimo v mestu Mobile, kjer je zgodovinski suženjski trg zamenjalo parkirišče. Poleg tega je od mestnega pristanišča iz 19. stoletja, ki je bilo ustanovljeno blizu suženjskega trga in železnice, zdaj ostalo samo še nekaj delcev. Stara fizična povezava med suženjsko tržnico in železnico je bila pred kratkim prekinjena. Te spremembe odpirajo ta vprašanja: kako bi morali konceptualizirati novo vrsto mu-
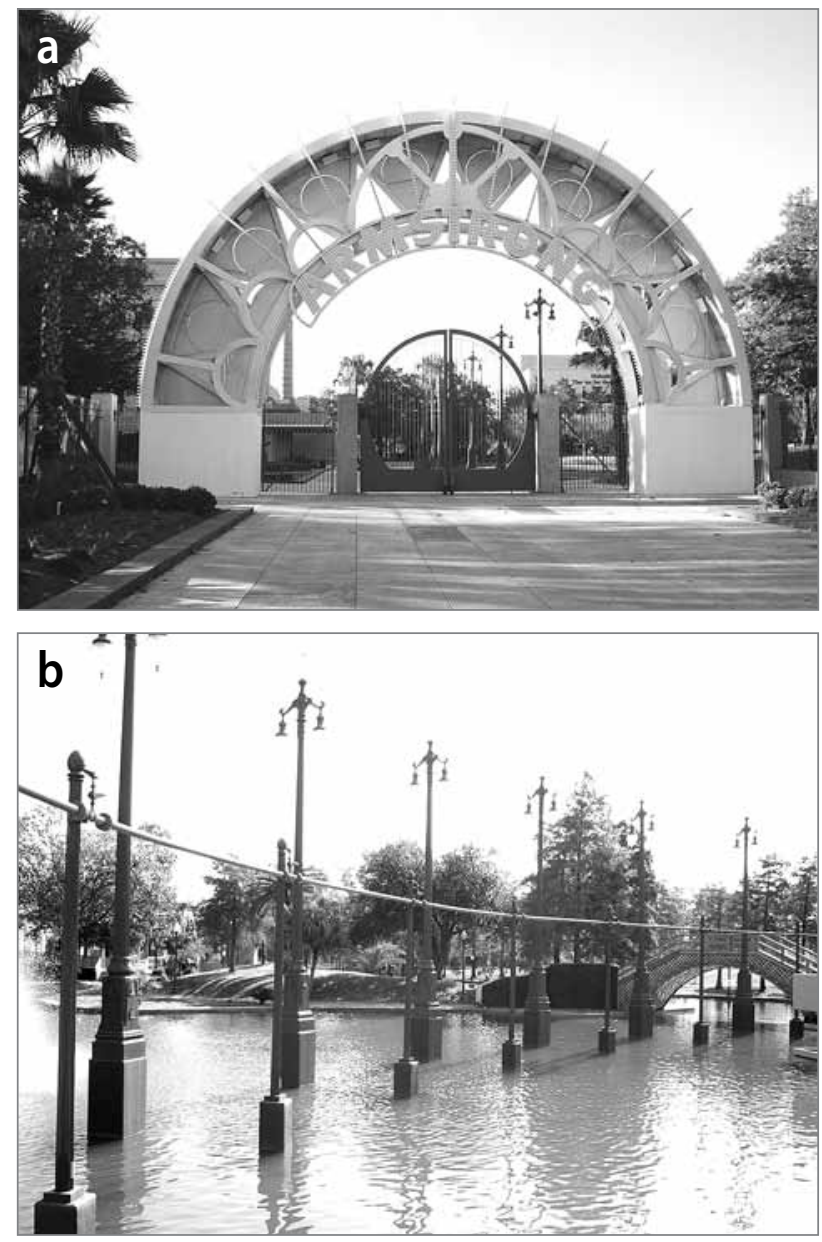

Slika 14: (a) Park Louisa Armstronga v New Orleansu; glavni vhod; (b) park Louisa Armstronga vnaša nekatere prvine tradicionalne angleške pokrajine v urbano okolje New Orleansa (foto: Marco Giliberti).

zeja afroameriške zgodovine na jugovzhodu Združenih držav? Kako lahko bolje uporabljamo, si predstavljamo, načrtujemo in preoblikujemo stavbe in območja afroameriške zgodovine? Kako lahko obnovimo in saniramo močno poškodovane kraje afroameriške zgodovine?

Analiza urbanizacije afroameriškega spomenika v Montgomeryju je pokazala, da je bil prostor, ki je bil v preteklosti namenjen trgovini s sužnji, po več desetletjih sprememb preoblikovan v glavni mestni trg (slika 13). Prostor se nahaja samo ulico proč od novega Muzeja Rose Parks. Vidna povezava med spomenikom in kapitolsko stavbo je morda najmočnejši pokazatelj družbene sprave po bojih v 60. in 70. letih 20. stoletja (Blair in Neil, 2000). Leta 1989 se je s postavitvijo spomenika državljanskim pravicam začelo dvajsetletno obdobje urbane prenove. Leta 2005 je bilo blizu spomenika ustanovljeno središče za državljanske pravice. Leta 2010 je bila zgrajena nova stavba neprofitne organizacije Southern Poverty Law Center, ki se bori proti nestrpnosti in diskriminaciji. To je zdaj najopaznejši objekt, če od spomenika gledamo proti kapitolski stavbi. Izra- 

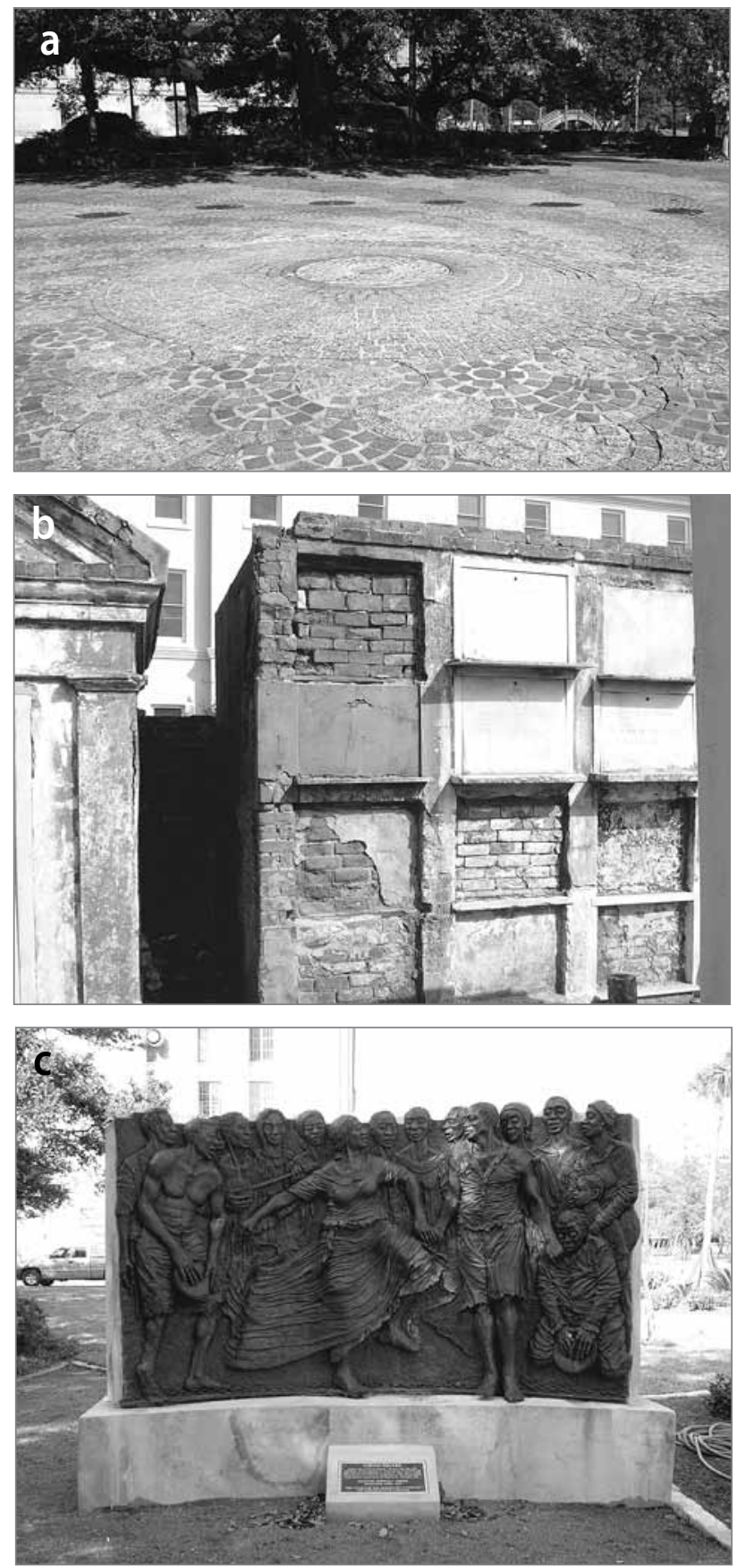

Slika 15: (a) Trg Congo je dobro znan del urbane pokrajine na južnem območju spominskega parka Louisa Armstronga v New Orleansu; (b) pokopališče sv. Ludvika št. 1 je del celote, ki najde vzrok za svoj obstoj v urbanistični mreži New Orleansa; (c) Afroameričani med plesanjem in petjem bamboule. Skulptura, ki jo je oblikoval Adewale Adenle, stoji v parku trga Congo v New Orleansu (foto: Marco Giliberti).

zita fizična in simbolna povezava med spomenikom in ulico razkriva, da so bile večplastne aritmetične povezave glavnega načrta ustvarjene za oblikovanje edinstvenega kraja. Cilj ohranitvenih načrtov in strategij je upočasnitev proces fizičnega propadanja in drobljenja zgodovinskih krajev, do neke mere pa izražajo tudi potrebo po združitvi strokovnih in ustvar-

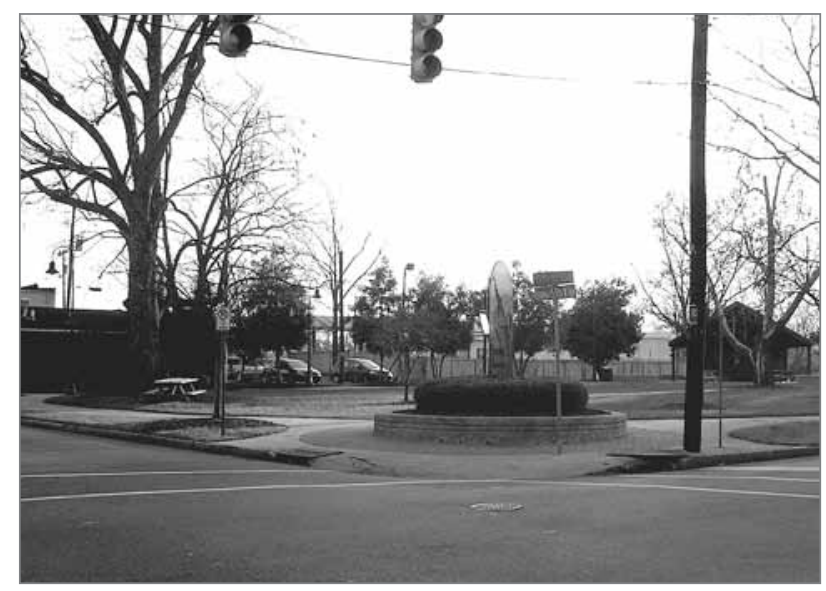

Slika 16: Kovinska silhueta v spomin na džezovskega skladatelja Erskina Hawkinsa. Spomenik stoji v prenovljeni afroameriški soseski Tuxedo v mestu Bessemer (foto: Marco Giliberti).

jalnih prizadevanj za njihovo ohranitev. Spomenik bi moral okrepiti družbeno reprodukcijo v Birminghamu, Memphisu in New Orleansu. Zvezna stanovanjska uprava (ang. Federal Housing Administration, v nadaljevanju: HUD) in mestna občina Birmingham se strinjata, da bi moral projekt urbane prenove vključevati tudi afroameriško dediščino kot del obnovitvenih načrtov, kot je projekt obnove območja Tuxedo Court (ang. Tuxedo Court HOPE VI Revitalization Project, v nadaljevanju: TCRP).

V Memphisu v zvezni državi Tennessee pa HUD financira projekt prenove soseske Vance. Načrtovalec Ken Reardon z univerze v Memphisu vodi projekt participativnega načrtovanja, ki se osredotoča na prenovo revne afroameriške soseske blizu mestnega središča. $V$ teh in drugih primerih je lokalni spomin osrednja strategija uspešne urbane prenove (Talen, 1999; Lah, 2001; Jankovič, 2001; Throgmorton, 2007). V New Orleansu so park Louisa Armstronga, ki ga je zasnovala arhitektka Robin Riley (sliki 14a in 14b), stari trg Congo in pokopališče sv. Ludvika št. 1 (sliki 15a in 15b) deli celote, ki najde vzrok za svoj obstoj v urbanistični mreži (Tretter, 2010; Evans, 2011). Novejša skulptura na trgu Congo, zgrajena leta 2010, je posvečena afroameriškim plesalcem in glasbenikom, ki so v 19. stoletju delovali v New Orleansu (slika 15c). V Birminghamu spomenik, posvečen alabamskemu džezovskemu skladatelju Erskinu Hawkinsu, stoji blizu TCRP (slika 16). Nenavadna mestna pokrajina se razteza samo nekaj ulic od zgodovinskega kraja nacionalnega pomena, posvečenega Martinu Luthru Kingu ml. (slika 17a), blizu starega afroameriškega okrožja Auburn Avenue v metropolitanski Atlanti (slika 17b). Zdaj v teh majhnih živobarvnih starih hišah živijo študenti in revni Afroameričani (Alderman, 2003). Turisti in študenti univerze v Atlanti pomagajo razbiti enolično sestavo soseske, v kateri prevladujejo Afroameričani. Na žalost v svoji raziskavi nismo podrobneje preučili odnosa med načrtovanjem in politiko spomina, saj je bil ta vidik doslej slabo raziskan. Leta 1996 je ame- 

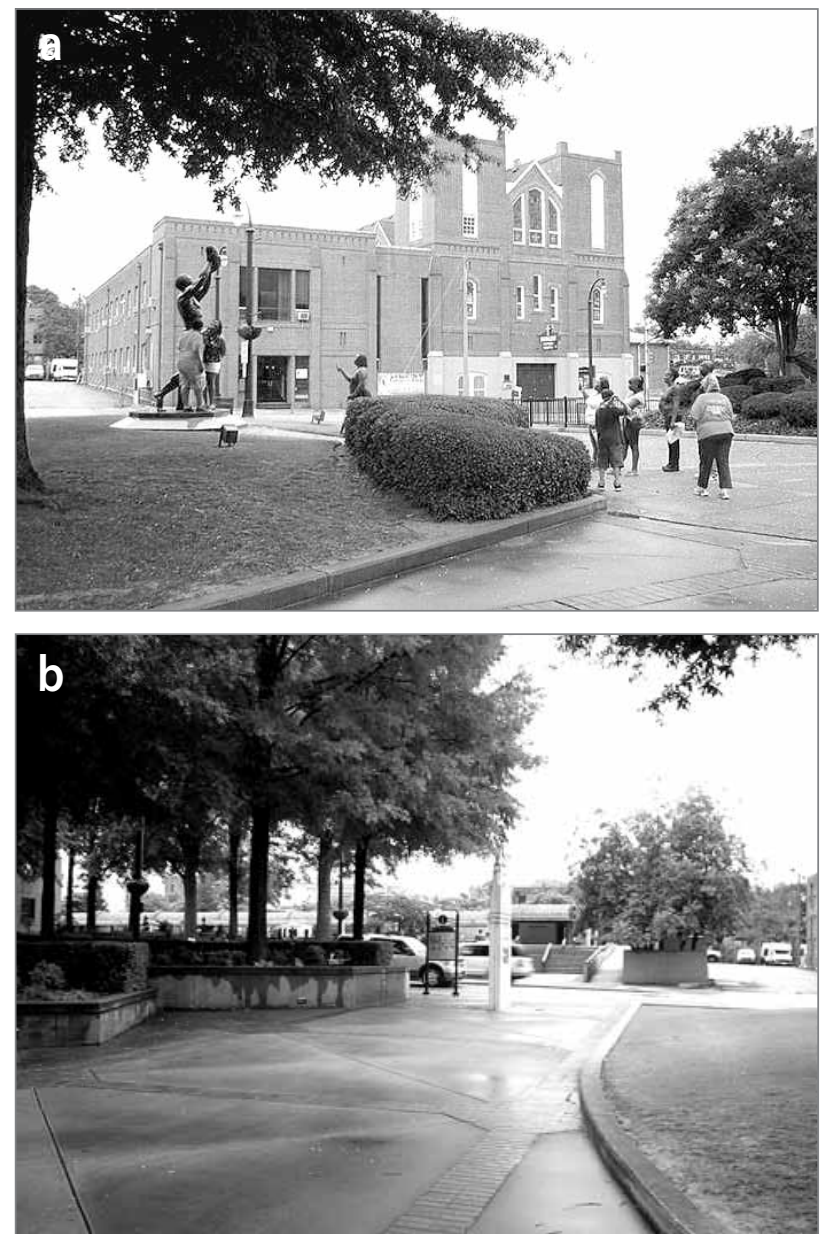

Slika 17: (a) Severna stran baptistične cerkve v Ebenezerju na zgodovinskem kraju, posvečenem Martinu Luthru Kingu ml. Pogled z ulice, v kateri je vhod v cerkev; (b) zgodovinski kraj nacionalnega pomena, posvečen Martinu Luthru Kingu ml. (notranjost). S kulturnim središčem mesta ga povezuje atlantski metropolitanski javni potniški sistem (ang. Metropolitan Atlanta Rapid Transit Authority; foto: Marco Giliberti).

riški kongres razglasil 87 kilometrov dolgo pot od Selme do Montgomeryja za pot zgodovinskega pomena (ang. Selma to Montgomery National Historic Trail, v nadaljevanju: SEMO); posvečena je pohodu za volilne pravice leta 1965 ter dogodkom in državljanom, ki so na njem sodelovali.

Leta 1965 je skupina brezposelnih črnih kajžarjev v okrožju Lowndes postavila šotore za pohodnike in aktiviste za državljanske pravice na pol poti med Selmo in Montgomeryjem. $\mathrm{V}$ spomin na ta dogodek so se načrtovalci in upravljavci leta 2006 odločili zgraditi središče za ozaveščanje o nacionalni dediščini (ang. interpretive center). Središče za ozaveščanje o nacionalni dediščini okrožja Lowndes (ang. Lowndes County Interpretive Center, v nadaljevanju: LCIC) v Haynevillu potrjuje, da so načrtovalci želeli dokumentirati in preučiti odnos med zgodovino gibanja za državljanske pravice in afroameriško zgodovino. Središče, ki je bilo zgrajeno ob avtocesti št. 80 (ang. Route 80), je zdaj del SEMO. V turističnih vodičih je ta kraj
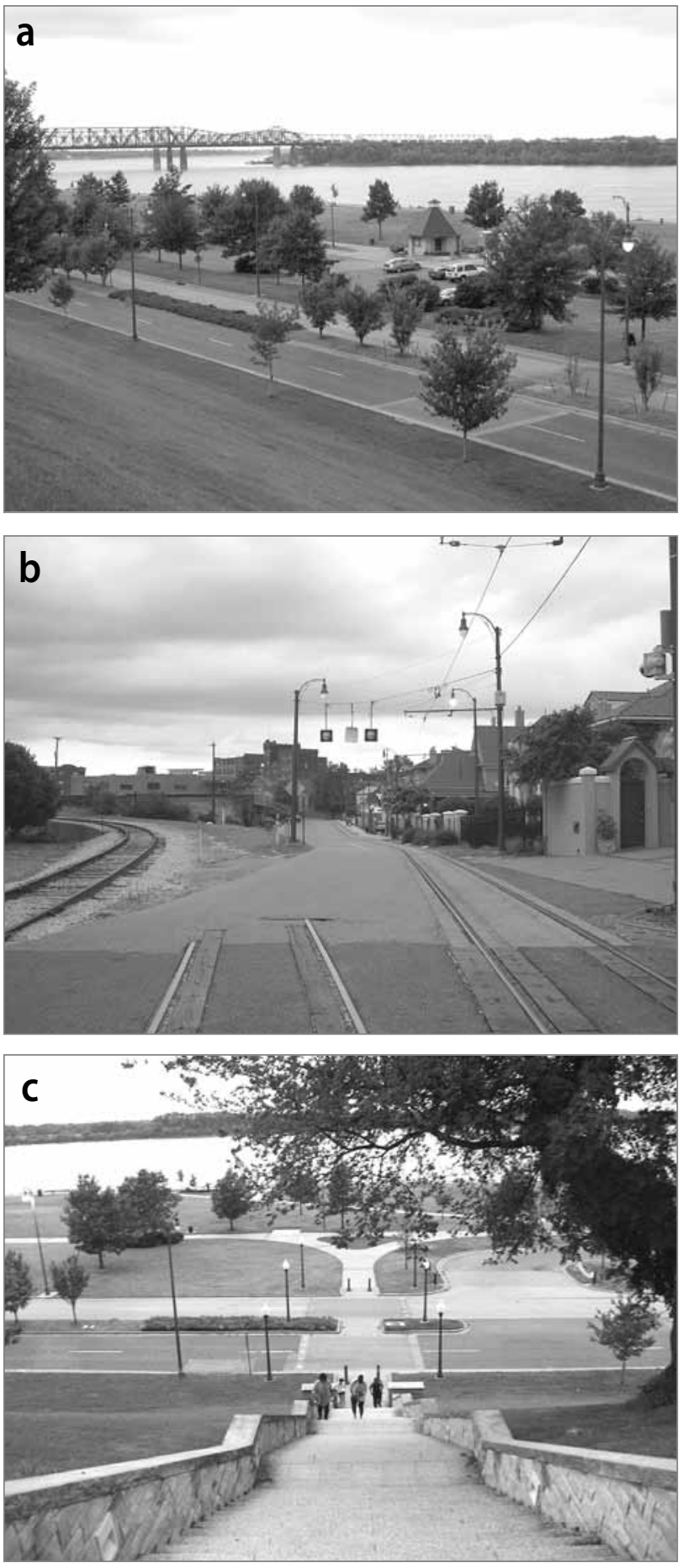

Slika 18: Memphis (a) staro rečno obrežje je bilo sanirano v prvem desetletju 21. stoletja; (b) stare železniške proge se združujejo na dvorišču luksuzne stavbe. Ta železnica že od nekdaj povezuje pristanišče s plantažami; (c) stopnice, ki vodijo od luksuzne stavbe do kraja, na katerem je bilo nekoč staro pristanišče (foto: Marco Giliberti).

opisan kot mesto šotorov in LCIC, ki ga obiskujejo šolske skupine, strokovnjaki, zgodovinarji in aktivisti. Območje mesta šotorov in LCIC povezuje s sosednjimi mesti avtobusna proga. Načrtovalci in lokalni upravljavci menijo, da je afroameriška dediščina dejavnik, ki lahko okrepi lokalni turizem na podeželskem vzhodu Alabame. LCIC prav tako izraža razvoj 


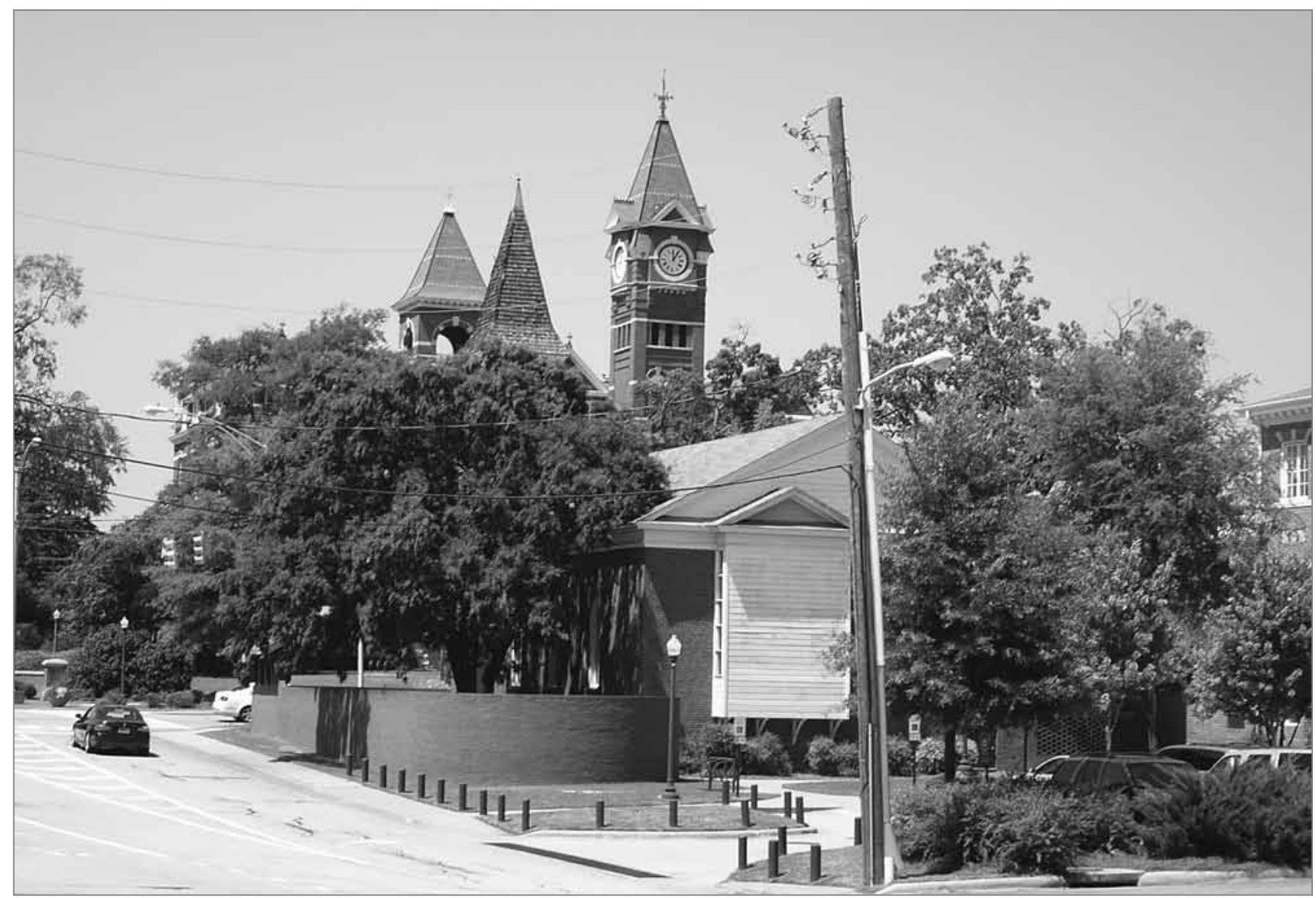

Slika 19: Auburn, Alabama. Staro mestno jedro je bilo preoblikovano v 20. stoletju (foto: Marco Giliberti).

novega pojava: praksa načrtovanja spomenikov afroameriške zgodovine vključuje nove strategije. Natančneje, praksa obeleženja zgodovinskega dogodka »na mestu, na katerem se je zgodil, in tako, kot se je zgodil, « postaja v zadnjih desetletjih med načrtovalci vse bolj priljubljena. Najbolje je, da je spomenik umeščen $\mathrm{v}$ pokrajino, $\mathrm{v}$ kateri se je zgodil zgodovinski dogodek. Načrtovalci menijo, da je upoštevanje tega načela dovolj, da zadosti željam afroameriške skupnosti. Ta praksa je že ustvarila določene prednosti. Spomenik, kot je LCIC, ima za stare borce za državljanske pravice veliko simbolno vrednost. Po drugi strani pa obstaja tveganje, da načrtovalci ustvarijo izolirano območje za Afroameričane. Čeprav se to ne zgodi vedno, obstaja tveganje, da ta tipologija muzejev (zaradi njihove lokacije v oddaljenem podeželskem mestu) ne izpolni načrtovalskih ciljev. Komu so namenjeni tovrstni muzeji? To je vprašanje, ki načrtovalca pripelje $\mathrm{k}$ splošnemu sklepu. Praksa načrtovanja spomenikov afroameriške zgodovine temelji na zapleteni množici postopkov, ki zahtevajo skupna prizadevanja različnih vrst skupnosti, ustanov in uradov.

Leta 2002 je mestni svet v Memphisu odobril glavni načrt za ureditev mestnega rečnega brega (ang. Memphis Riverfront Master Plan, v nadaljevanju: MRMP), da bi ponovno združili mesto in reko. Načrt je predvidel velik nabor dejavnosti, namenjenih ohranitvi zgodovinskih območij. Projekt ureditve ulice Beale (ang. Beale Street Landing Project, v nadaljevanju: BSLP) je bil usmerjen $\mathrm{v}$ obnovo večjega dela starega pristanišča. Mestna občinska uprava meni, da bi moral BSLP delovati kot pilotni projekt MRMP. Novo urejeno rečno obrežje naj bi delovalo kot prvorazredno pristanišče za velike ladje in male čolne. $V$ ta namen je bil razpisan oblikovalski natečaj, s katerim so bili ti cilji najučinkoviteje doseženi. Načrtovalci MRMP in BSLP razumejo kot pilotni poseg za preoblikovanje Memphisa. Trenutno je memphiško rečno obrežje dobro vzdrževano travnato območje, ki se od stare železnice spušča proti reki Mississippi (sliki 18a in 18b). Na vrhu brega so luksuzne hiše in stopnice vodijo do kraja, na katerem je bilo nekoč staro pristanišče (slika 18c). Kot mnoga druga pristanišča na jugovzhodu ZDA je tudi to povezano $\mathrm{z}$ afroameriško zgodovino. Edino afroameriško zgodovinsko obeležje v mestu je spomenik, posvečen Tomu Leeju, osvobojenemu sužnju, ki je v 20. letih prejšnjega stoletja rešil veliko potnikov s potapljajoče se ladje v Memphisu.

Zgodovina in kultura sta temi, ki sta pritegnili pozornost načrtovalcev na sicer nezanimivih območjih. V primeru javnega potniškega sistema v Atlanti (ang. Metropolitan Atlanta Rapid Transit Authority, v nadaljevanju: MARTA) je bila med načrtovalci in upravljavci, ki so želeli oblikovati glavni načrt na metropolitanski ravni, najpomembnejša tema kulture (in 
financ). Ali načrtovalci sistema MARTA raje poudarjajo medsebojne povezave med kulturnimi in finančnimi ustanovami, kot povezujejo različna urbana gospodarstva? Delni odgovor na to vprašanje sta leta 1997 ponudila sociologa Christopher Bollinger in Keith Ihlanfeldt, ki sta trdila, da je sistem MARTA od svojega nastanka le malo vplival na skupno zaposlovanje prebivalcev. $S$ tem se je strinjal tudi Larry Keating, ki je potrdil, da ta sistem ni imel nobenega vpliva na zmanjšanje rasnih in razrednih razlik ali na nenačrtno širjenje mesta (glej Keating, 2001). Sistem MARTA je bil zasnovan v obdobju boja za državljanske pravice in zgrajen $\mathrm{v}$ desetletjih, ki so temu sledila. Po podatkih njegove uradne spletne strani ga zdaj uporabljajo potniki iz vseh sosesk v Atlanti. Zaradi zgodovinskih krajev pa so se prometni načrtovalci začeli osredotočati na stare afroameriške soseske, kot so Old Fourth Ward, Sweet Auburn, Georgia State, Washington Park in West End, medtem ko v Alabami zdaj načrtovalci eksperimentirajo predvsem $\mathrm{z}$ univerzitetnimi mesti. Leta 2011 so se v mestu Auburn v okrožju Lee mestni upravljavci odločili poimenovati park po Martinu Luthru Kingu ml. Auburn je znan po svoji javni univerzi, ki se je pred kratkim odločila dodatno urbanizirati svoj kampus. To načrtovalcem in upravljavcem ponuja veliko priložnost, da pokažejo, kako lahko obravnavajo kompleksna načrtovalska vprašanja in vzpostavijo nove odnose med načrtovanjem mest, univerz in obeležij afroameriške zgodovine (slika 19).

\section{Sklep: razumevanje spomenika kot mreže različnih krajev}

V članku se obravnavajo spomeniki v okviru načrtovanja mest na ameriškem jugu. $V$ prvem delu so preučeni politični in družbeni vidiki zakonodaje Jima Crowa, pri čemer se osredotoča na različne poskuse reform v 20. stoletju. Obravnavane so družbene, kulturne in gospodarske razmere, $\mathrm{v}$ katerih se je razvijalo gibanje za državljanske pravice. V naslednjem poglavju je predstavljena utemeljena potreba za to, da se oblikujejo nove strategije za zgodovinsko obravnavo v 20. stoletju. Postkolonialne študije so uvedle vidik spomina, ki je postajal vse pomembnejši $\mathrm{v}$ znanstvenem diskurzu. Na podlagi tega se je razvila razprava, $\mathrm{v}$ kateri se poudarjata kolektivni spomin in lokalna zgodovina $v$ povezavi z institucionalizirano zgodovino (vendar ne na njen račun). $V$ tretjem in četrtem poglavju je preučen vpliv spomenikov v alabamskih mestih in na podeželju. Predstavljeni so primeri o tem, kako so upravljavci uporabljali načrte za zaščito afroameriške dediščine.

Peto poglavje se osredotoča na vsebino načrtovalskih dejavnosti in v njem so predstavleni nekateri vidiki ideologije, ki je oblikovala ameriško regionalno kulturo 20. stoletja. Ta ideologija je oblikovala afroameriško pokrajino po vseh ZDA, zaradi česar je območje Črnega pasu primerno za preučevanje zgo- dovine preobrazbe ameriških spomenikov. To poglavje določa tudi pogoje za drugačno razmišljanje o spomenikih, in sicer najprej z opisom izbranega števila nastajajočih pokrajin, ki lahko postanejo del večje mreže krajev. To lahko dosežemo zato, ker lahko presečišče načrtovanja in spomina okrepi identiteto kraja. V šestem poglavju smp predlagali, naj se afroameriška spomeniška pokrajina razume kot prostorska sestavljenka, ki se spreminja v skladu $\mathrm{z}$ ravnjo notranje kohezije skupin, $\mathrm{z}$ ravnjo bližine grozdov avtonomnih okrajev in gostote družinskih povezav ter v skladu z ravnmi sobivanja subkultur, ki se oblikujejo $\mathrm{z}$ družbenim razslojevanjem.

$S$ teoretičnega vidika načrte obeležij afroameriške zgodovine določajo različni koncepti, vključno z različnimi teorijami. Poleg tega so se za tovrstne načrte iskale predvsem nove oblike odobritve, namenjene praktični uporabi spomina za izboljšanje družbe v celoti. To novo zavedanje temelji na obljubljeni zavezanosti peščice arhitektov in načrtovalcev, ki so pozornejši na temeljne spremembe v prostoru, ki so se zgodile konec 60. let 20. stoletja. Načrtovalske tehnike in demokracija so se začele združevati v 60 . letih, po stoletju zatiranja črnskega prebivalstva. Raven usklajenosti med načrtovalci, upravljavci in drugimi akterji, vključenimi v prostorsko preoblikovanje afroameriške spomeniške pokrajine, pa določa usklajevanje med različnimi ravnmi oblasti. Ta razslojenost izvira iz zgodovine, $s$ katero je bila tudi pogojena, in je pustila fizične sledi po vsej ameriški pokrajini. Kot pravi Michel Foucault, te sledi pričajo o prisotnosti bedakov v mestu. Po eni strani je sodobno mesto pripravljeno sprejeti te sledi kot del skupnega palimpsesta, po drugi pa je ta proces še vedno v povojih.

Trenutne raziskave potrjujejo velike spremembe v načrtovanju obeležij afroameriške zgodovine $\mathrm{v}$ zadnjih treh desetletjih. V skladu s teorijo Roda Barnetta, ki poudarja pomembnost nelinearnega razmišljanja o pokrajini, je za znanstveno in načrtovalsko izražanje načrtovanja obeležij afroameriške zgodovine treba upoštevati več osnovnih načel (prostorsko, politično in okolijsko; Barnett, 2000). Poleg teh načel moramo upoštevati tudi splošno razdrobljenost afroameriških zgodovinskih krajev po vsej Alabami. V mnogih primerih je ta razdrobljenost povezana s slabo trpežnostjo tradicionalne afroameriške arhitekture. Zaradi velike gostote afroameriških zgodovinskih krajev v Alabami so potrebne dodatne raziskave, $s$ katerimi bi lahko preučili povezavo med spominom in fizično funkcijo teh krajev. Dodatne raziskave bi se morale osredotočiti predvsem na iskanje arhitekturnih predlogov, s katerimi se izrecno prizadeva za oblikovanje kohezivnejše afroameriške spomeniške pokrajine. $S$ tega vidika ponuja ohranitev afroameriške dediščine priložnost za prenovo mesta in ustvarjanje prostora za vse.

\section{Marco Giliberti}

Auburn University, College of Architecture, Design and Construction, Landscape Architecture Program, Auburn, Alabama, ZDA

E-pošta:mzg0014@auburn.edu 


\section{Opombe}

[1] Alabama ima 4.802.740 prebivalcev, od teh jih je 1.272.726 afriškega porekla. Območje Črnega pasu v Alabami pokriva številna okrožja z visokim odstotkom Afroameričanov. Štirideset odstotkov prebivalcev okrožja Jefferson je afriškega porekla, na alabamskem podeželju pa je odstotek še višji. V okrožju Dallas znaša delež Afroameričanov 80 \% (ameriški popisni urad, 2011).

[2] Alabamski romanopisec Harper Lee meni, da je dejanje spominjanja proces, pri katerem se stvari, ki se jih spominjamo, spremenijo v žive opise krajev. Spominjanje je lahko boleče, vendar je nujno, če želimo pozdraviti kolektivno izgubo spomina.

\section{Zahvala}

Zahvaljujem se metodistični baptistični skupnosti Shiloh v Notasulgi v Alabami ter Jocelyn Zanzot, Charlene LeBleu in Jamesu Throgmortonu, da so me seznanili s to temo. Z Ricardom Pièm Ninotom sva imela živahno razpravo o odnosu med krajinsko arhitekturo in Alabamo. Prejšnja različica članka je bila predstavljena na Rhodes Collegeu v Memphisu v okviru programa okolijskih študij in znanosti. Anonimni recenzenti so predložili dragocene opombe in predloge za izboljšanje tega članka.

\section{Viri in literatura}

Abramson, D. (1996): Maya Lin and the 1960s: Monuments, time lines, and minimalism. Critical Inquiry, 22(1), str. 679-709. DOI: $10.1086 / 448813$

Alderman, D. K. (2003): Street names and the scaling of memory: The politics of commemorating Martin Luther King, Jr. within the African-American community. Area, 35(2), str. 163-173. DOI: 10.1111/1475$-4762.00250$

Anstey, R. (1970): Numbers and the slave trade. The Journal of African history, 11(3), str. 457-459. DOI: 10.1017/S0021853700010306

Assmann, J. (2011): Communicative and cultural memory. Knowledge and Space, 4(1), str. 15-27. DOI: 10.1007/978-90-481-8945-8_2

Azaryahu, M., in Foote, K. E. (2008): Historical space as narrative medium: On the configuration of spatial narratives of time at historical sites. GeoJournal, 73(3), str. 179-194. DOI: 10.1007/s10708-008-9202-4

Barba Casanovas, R. (2010) Arguments in the project of the landscape. V: Piè Ninot, R. (ur.): Rosa Barba Casanovas 1970-2000 works and words, str. 108-109. Barcelona, Asflor ediciones.

Barnett, R. (2000): Exploration and discovery: A nonlinear approach to research by design. Landscape Review: An Asia-Pacific Journal of Landscape Architecture, 6(2), str. 1-18.

Benjamin, W. (2005): Excavation and memory. V: Bullock, M. P, Jennings, M. W., Eiland, H., in Smith, G. (ur.): Selected Writings, 2, str. 576. Cambridge, Harvard University Press.

Blair, C., in Neil, M. (2000): Reproducing civil rights tactics: The rhetorical performances of the civil rights memorial. Rhetoric Society Quarterly, (30)2, str. 31-55. DOI: 10.1080/02773940009391174

Bollinger, C. R., in Ihlanfeldt, K. R. (1997): The impact of rapid rail transit on economic development: The case of Atlanta's MARTA. Journal of Urban Economics, 42(2), str. 179-204. DOI: 10.1006/juec.1996.2020

Boyer, M. C. (2011): The city of collective memory. V: Olick, J. K., Vinitzky-Seroussi, V., in Levy, D. (ur.): The collective memory reader, str. 378380. Oxford, Oxford University Press.
Connerly, C. (2005): The most segregated city in America: City planning and civil rights in Birmingham, 1920-1980. Charlottesville, University of Virginia Press.

Cosgrove, D. (1978): Place, landscape, and the dialectics of cultural geography. Canadian Geographer, 22(1), str. 66-72. DOI: 10.1111/j.1541-0064.1978.tb01218.x

Curtain, P. D. (1969): The Atlantic slave trade: A census. Madison, University of Wisconsin Press.

Dekel, I. (2009): Ways of looking: Observation and transformation at the Holocaust memorial, Berlin. Memory Studies, 2(1), str. 71-86. DOI: $10.1177 / 1750698008097396$

Deleuze, G. (1994): Difference and repetition. New York, Columbia University Press.

Deleuze, G., in Guattari, F. (1972): L'Anti-Oedipe. Pariz, Les Editions de Minuit.

Dewey, J. (1927): The public and its problems. New York, Holt Press.

Diouf, S. A. (2007): Dreams of Africa in Alabama: The slave ship Clotilda and the story of the last Africans brought to America. New York, Oxford University Press.

Dwyer, O. J., in Alderman, D. H. (2008a): Civil rights memorials and the geography of memory. Čikago, Center for American Places at Columbia College.

Dwyer, O. J., in Alderman, D. H. (2008b): Memorial landscapes: Analytic questions and metaphors. GeoJournal, 73(3), str. 165-178. DOI: 10.1007/ s10708-008-9201-5

Dyer, J., in Bailey, C. (2008): A place to call home: Cultural understandings of heir property among rural African Americans. Rural Sociology, 73(3), str. 317-338. DOI: 10.1526/003601108785766598

Erll, A. (1999): Regional integration and (trans)cultural memory. Cultural Geographies, 6(3), str. 251-283.

Evans, F. W. (2011): Congo square: African roots in New Orleans, Lafayette, University of Louisiana Press.

Flynt, W (2004): Alabama in the twentieth century. Tuscaloosa, University of Alabama Press.

Freire, P. (2007): Pedagogy of the oppressed. New York, Continuum.

Gallagher, J. V. (1999): Memory and reconciliation in the Birmingham Civil Rights Institute. Rhetoric \& Public Affairs, 2(2), str. 303-320. DOI: 10.1353/rap.2010.0067

Giliberti, M. (2011): Cross-regional landscape design and cultural identity: The African-American memorial landscape in the US Southeast. Predavanje $v$ okviru podiplomskega programa okolijskih študij na Rhodes Collegeu, 7. februarja 2011 v Memphisu v Tennesseeju. Tipkopis.

Gleason, P. (1983): Identifying identity: A semantic history. The Journal of American History, (69)4, str. 910-931. DOI: 10.2307/1901196

Google Maps (2013): Notasulga, Alabama. Dostopno na: https://maps. google.com (sneto 5. 1. 2013).

Gray, F. D. (1998): The Tuskegee syphilis study. Montgomery, AL, Black Belt Press.

Halbwachs, M. (1980): The collective memory. New York, Harper \& Row. Hamilton, V. (1977): Alabama: A history. New York, Norton.

Hayden, D. (1997): The power of place: Urban landscapes as public history. Cambridge, MA, MIT Press.

Hoelscher, S., in Alderman, D. H. (2004): Memory and place: Geographies of a critical relationship. Social \& Cultural Geography, (5)3, str. 347355. DOI: 10.1080/1464936042000252769

Huntington, S. (1998): The clash of civilisations and the remaking of world order. New York, Simon \& Schuster. 
Jackson, J. B. (1980): The necessity of ruins. Cambridge, MA, University of Massachusetts Press.

Jankovič, A. (2001): Zapuščina arhitekturne in tehnične infrastrukturne dediščine. Urbani izziv, 12(1), str. 52-58. DOI: 10.5379/urbani-izziv-2001-12-01-007

Jencks, C. (2002): New paradigm in architecture. Cambridge, MA, Yale University Press.

Jones, J. H. (1993): Bad blood: The Tuskegee syphilis experiment. New York, The Free Press.

Keating, L. (2001): Atlanta: Race, class, and urban expansion. PhiladeIphia, Temple University Press.

King, M. L. (1958): Stride toward freedom: The Montgomery story. New York, Harper \& Row.

Krauss, R. (1979): Sculpture in the expanded field. October, 8(2), str. 30-44.

Lah, L. (2001): Od arhitekturnega konservatorstva, obnove in prenove do integralnega varstva dediščine (teoretska in konceptualna izhodišča). Urbani izziv, 12(1), str. 31-45. DOI: 10.5379/urbani-izziv-2001-12-01-004

Lee, H. (2010): To kill a mockingbird. New York, Grand Central Publishing. Lepore, J. (2010): The whites of their eyes. Princeton, Princeton University Press.

Lowenthal, D. (1996): Possessed by the past: The heritage crusade and the spoils of history. Glencoe, IL, Free Press.

Morrison, T. (1987): Beloved. New York, Alfred Knopf.

Myrdal, G. (1944): An American dilemma: The Negro problem and modern democracy. New York, Harper \& Bros.

Nora, P. (1989): Between memory and history: Le lieu de memoire. Representations, 26(2), str. 7-24. DOI: 10.2307/2928520

Payne, J. (2007): An expensive death: Walter Benjamin at Portbou. European Judaism, 40(2), str. 102-105. DOI: 10.3167/ej.2007.400209

Reps, J. W. (1992): The making of urban America: A history of city planning in the United States. Princeton, Princeton University Press.

Reverby, S. M. (2001): More than fact and fiction: Cultural memory and the "Tuskegee Syphilis Study". The Hastings Center Report, (31)5, str. 22-28. DOI: 10.2307/3527701

Rose-Redwood, R., Alderman, D., in Azaryahu, M. (2008): Collective memory and the politics of urban space: An introduction. GeoJournal, 73(3), str. 161-164. DOI: 10.1007/s10708-008-9200-6

Sandage, A. S. (1993): A marble house divided: The Lincoln memorial, the civil rights movement, and the politics of memory, 1939-1963. The Journal of American History, 80(1), str. 135-167. DOI: 10.2307/2079700

Secchi, B. (1989): Un progetto per l'urbanistica. Turin, Einaudi.

Sims, L. (2009): A note from president Liz Sims. Dostopno na: http://shilohcommfound.com (sneto 4. 1. 2013).

Solà-Morales, I. (1995): Terrain Vague. V: Davidson, C. C. (ur.): Anyplace, str. 118-123. Cambridge, MA, MIT Press.

Talen, E. (1999): Sense of community and neighbourhood form: An assessment of the social doctrine of new urbanism. Urban Study, 36(8), str. 1361-1379.

Throgmorton, J. A. (2007): Inventing the greatest: Crafting Louisville's future out of story and clay. Planning Theory, 6(3), str. 237-262. DOI: $10.1177 / 1473095207082033$

Tretter, E. M. (2010): The power of naming: The toponymic geographies of commemorated African-Americans. The Professional Geographer, 63(1), str. 34-54. DOI: 10.1080/00330124.2010.537936
Tuan, Y. F. (2001): Life as a field trip. Geographical Review, 91(1-2), str. 41-45. DOI: 10.2307/3250803

Ware, K. (2011): Shiloh community restoration foundation, Inc. Dostopno na: http://www.shilohcommfound.com (sneto 19. 9. 2012).

Wasserman, J. R. (1997): To trace the shifting sands: Community, ritual, and the memorial landscape. Landscape Journal, 17(1), str. 42-61.

Wood, G. S. (2011): No thanks for the memories. The New York Review of Books, 58(1), str. 40-42.

Zinn, O. (2005): A people's history of the United States: 1492 to present. New York, Harper. 